\title{
BEYOND REFUSAL TO DEAL: A CROSS-ATLANTIC VIEW OF COPYRIGHT, COMPETITION, AND INNOVATION POLICIES
}

\author{
Ariel Katz \\ PAUL-ERIK VeEL*
}

Commentators have long perceived a tension between antitrust law and intellectual property (IP) law. Even if the two bodies of law pursue the same long-term goals, such as innovation and consumer welfare, ${ }^{1}$ their methods and immediate aims appear at times to conflict. Broadly speaking, IP law aims to create limited, legally sanctioned, zones of exclusivity; by providing innovators with supracompetitive returns for their innovations ex post, it seeks to encourage them to research and develop those innovations ex ante. ${ }^{2}$ By contrast, antitrust law aims to facilitate the operation of competitive markets by putting checks on firms possessing market power; it thereby seeks to ensure that these firms do not use their market power to exclude rivals and stifle competition. While both legal regimes may be directed toward a common end, careful calibration of legal doctrine is necessary to ensure that neither regime's proximate purpose overwhelms that common end.

\footnotetext{
* Respectively, Associate Professor, Innovation Chair Electronic Commerce, Faculty of Law, University of Toronto; and Adjunct Professor, Faculty of Law, University of Toronto.

${ }^{1}$ For example, Marina Lao has observed:

Much has changed in the last twenty years in the antitrust approach to intellectual property. Prior to the 1980s, the predominant view of the antitrust and intellectual property laws was that they conflict because the former protects competition while the latter permits monopoly. Courts and academics alike considered intellectual property rights as exceptions to the antitrust law that must be narrowly construed. The notion that the two bodies of law are diametrically opposed has since given way to the perspective that they are complementary, not conflicting, because they share the common goal of promoting innovation and maximizing consumer welfare.

Marina Lao, Unilateral Refusals to Sell or License Intellectual Property and the Antitrust Duty to Deal, 9 Cornell J.L. \& Pub. Pol'y 193, 193 (1999).

${ }^{2}$ We use the terms "zones of exclusivity" and "supracompetitive returns" rather than "monopolies" and "market power" to avoid the confusion and controversy about what the latter terms mean or should mean in the antitrust context. See generally Ariel Katz, Making Sense of Nonsense: Intellectual Property, Antitrust, and Market Power, 49 ArIz. L. Rev. 837 (2007).
} 
Different jurisdictions can and do reach different conclusions about that calibration. These differences can be both general (e.g., what subject matter can be protected, or the term of protection) and specific. This article focuses on a specific legal issue that has generated a great deal of controversy: when, if ever, an IP holder's unilateral refusal to license its IP right may trigger antitrust liability. Many view the United States and the European Union as having adopted very different approaches to this question. Conventional wisdom holds that EU competition law is far more willing than U.S. antitrust law to override firms' unilateral decisions whether to license their intellectual property rights (IPRs) in the interest of promoting competition. ${ }^{3}$ This conventional wisdom stems from a line of cases over the last two decades holding that owners of IPRs that possessed a dominant position in a market and refused to license IPRs to others in particular circumstances abused their dominant position in violation of EU competition law. In those cases, the courts regarded a mandate to license the IPRs as an appropriate remedy. Although controversial in the European Union itself, these cases appear even more controversial to many American commentators. Generally, these commentators have charged that imposing antitrust liability on such refusals to license undercuts a fundamental constituent of IPRs: the right to exclude others. Imposing liability in these circumstances thereby undermines the very incentives for investment and innovation that IPRs seek to provide, and likely reduces longrun social welfare, which both antitrust and IP laws seek to promote.

Thus, for example, in response to the decision in the Microsoft case, ${ }^{4}$ the U.S. Assistant Attorney General for the Antitrust Division took the unusual step of publicly criticizing the ruling of the European Court of First Instance (CFI). In a press release issued only hours after the CFI handed down its

\footnotetext{
${ }^{3}$ See, e.g., Rita Coco, Antitrust Liability for Refusal to License Intellectual Property: A Comparative Analysis and the International Setting, 12 MArQ. InTELL. Prop. L. Rev. 1, 3 (2008) ("A comparative analysis of the current European and American systems - the two most mature for both antitrust and IP - shows that the former tends to downplay IP rights in favor of competition, whereas the latter tends to curtail the imperative of competition to preserve the exclusivity based upon IP rights. Yet these are only trends, and on the whole the two systems are still largely unsettled on the matter."); Katarzyna A. Czapracka, Where Antitrust Ends and IP Begins-On the Roots of the Transatlantic Clashes, 9 Y ALE J.L. \& Tесн. 44, 47 (2007) ("There have been virtually no decisions condemning a unilateral refusal to license of a valid intellectual property right (IPR) in the United States. By contrast, in the European Union, IP may be treated as an essential facility and courts and competition authorities may request that a dominant company shares its IP with competitors."); Eleanor M. Fox, A Tale of Two Jurisdictions and an Orphan Case: Antitrust, Intellectual Property, and Refusals to Deal, 28 Fordham InT'L L.J. 952 (2005); Melanie J. Reichenberger, The Role of Compulsory Licensing in Unilateral Refusals to Deal: Have the United States and European Approaches Grown Further Apart After IMS?, 31 J. CoRP. L. 549, 550 (2006) ("The interface between intellectual property and antitrust laws has always been an interesting one, especially when comparing the differing approaches within the international community. Most recently, it seems that the United States and the European Community approaches to dealing with unilateral refusals to deal have grown further apart.").

${ }^{4}$ Case T-201/04, Microsoft Corp. v. Comm'n, 2007 E.C.R. II-3601.
} 
decision, he expressed the concern that "the standard applied . . by the CFI, rather than helping consumers, may have the unfortunate consequence of harming consumers by chilling innovation and discouraging competition."

For some critics, Microsoft and similar decisions signal an unhealthy European appetite for interventionist regulation at odds with the fundamental principles of a free economy ${ }^{6}$ or manifest a protectionist trade policy that disadvantages foreign firms doing business in Europe. ${ }^{7}$ For others, the decisions reflect a myopic approach that favors the short-term benefits of competition over the long-term benefits of innovation. ${ }^{8}$ Under these accounts, a serious rift, perhaps a chasm, exists between the European Union and the United States: the United States supposedly protects IP rights more vigorously, does not exhibit the same regulatory appetite as the European Union, and embraces a superior long-term pro-IP and pro-innovation approach. Even commentators who approve the use of antitrust to compel IP owners to license in appropriate cases share the view that, on this point, Europe and the United States clearly diverge. ${ }^{9}$

In this article, we argue that, at least in the context of copyright law, this analysis of trans-Atlantic differences is incomplete and potentially misleading. By focusing on only one aspect of antitrust doctrine-here, unilateral refusals to license-the conventional wisdom neglects other important dimensions of the two jurisdictions' competition and innovation laws. We maintain that any comparative analysis of the respective jurisdictions' innovationfriendliness must also consider (1) as a matter of legal substance, the existence of doctrines internal to intellectual property law that limit IPRs to facilitate both traditional and innovative competition ${ }^{10}$ and (2) as a matter of legal

${ }^{5}$ Press Release, U.S. Dep't of Justice, Assistant Att'y Gen. for Antitrust, Thomas O. Barnett, Issues Statement on European Microsoft Decision (Sept. 17, 2007), available at http://www. justice.gov/atr/public/press_releases/2007/226070.pdf.

${ }^{6}$ See e.g., François-Henri Briard, A Costly and Suspect Offensive, InT'L Herald TriB., Apr. 28, 2007, at 4.

${ }^{7}$ See Daniel F. Spulber, Competition Policy and the Incentive to Innovate: The Dynamic Effects of Microsoft v. Commission, 25 YALE. J. ON Reg. 247, 283-84 (2008).

${ }^{8}$ See id. at 285-98; see also Briard, supra note 6.

${ }^{9}$ Beatriz Conde Gallego, Unilateral Refusal to Licence Indispensable Intellectual Property Rights-US and EU Approaches, in Research Handbook on Intellectual Property and Competition Law 215 (Josef Drexl ed., 2008); François Lévêque, Innovation, Leveraging and Essential Facilities: Interoperability Licensing in the EU Microsoft Case, 28 WorLd CoMPETITION 71, 72 (2005); Fox, supra note 3, at 952. But see Angelo Castaldo \& Antonio Nicita, Essential Facility Access in Europe: Building a Test for Antitrust Policy, 3 Rev. L. \& Econ. 83 (2007); Antonio Nicita \& Giovanni B. Ramello, Property, Liability and Market Power: The Antitrust Side of Copyright, 3 REv. L. \& ECON. 767 (2007) (suggesting that antitrust liability might be available in both jurisdictions).

${ }^{10}$ We use the term "innovative competition" to denote innovations that compete with the copyrighted work. Innovative competition is distinct from perfectly substitutive competition (i.e., identical or near-identical works) and from innovations that may not compete at all with the 
process, the ways in which those doctrines interact with antitrust law and its actual enforcement. ${ }^{11}$ Focusing principally on copyright protection, this article demonstrates that doctrines internal to U.S. copyright law limit the scope of copyright protection, often to curb the potential anticompetitive use of copyrights, in ways that European copyright laws generally do not. Thus, even if one accepts that European competition law places greater constraints on copyright owners' unilateral licensing decisions than does U.S. antitrust law, it does not follow that overall protection for copyrighted works is stronger in the United States than it is in Europe. To the contrary, as will be detailed below, copyright protection has been in some key respects weaker in the United States than it has been in Europe, particularly in circumstances when stronger copyright protection might harm innovative competition.

A holistic assessment of a jurisdiction's overall innovation friendliness may also require looking beyond the substantive rules of copyright and antitrust laws. In particular, it may require looking at how the process of antitrust law constrains the exercise of IP rights. This inquiry provides another reason to question claims about America's pro-IP bias. Even if modern U.S. antitrust law tends to be more self-restrained in its application to IP-related conduct, some unique features of the U.S. antitrust legal process tend de facto to constrain IP holders in ways that European legal process does not. In particular, we will argue, the predominance of private antitrust litigation in the United States, coupled with the availability of class actions, extensive discovery, treble damages, and a well-established antitrust bar, can be imposing checks on IP owners that do not exist in Europe. Indeed, these differences may justify a conclusion that, contrary to common wisdom, copyright protection in the United States is actually weaker than in Europe in some key respects.

This article will make several points, which we present in order of increasing complexity, and, we expect, decreasing consensus. We begin by pointing out that any evaluation of a jurisdiction's pro-innovation stance based on a single doctrine (such as the treatment of refusals to deal) is incomplete and potentially misleading.

Our second point is that, at least in the copyright area, once the analysis moves beyond refusals to deal and considers, among other things, the role that doctrines internal to copyright law play in circumscribing its scope, a different

copyrighted work. We use the term to highlight the point that U.S. copyright law tolerates (or even encourages) not only innovation that has no effect on the market for the copyrighted work, but also innovation that may compete with it, especially if it adds something else that the existing work is lacking.

${ }^{11}$ Of course, other policies might be relevant as well. For example, extremely favorable tax policies towards innovators could make one jurisdiction more hospitable to innovators even if it provides weaker IP protection and has adopted more aggressive antitrust policies. In this article, however, we hold constant all other policy differences and focus on only antitrust and IP laws. 
picture emerges. We demonstrate that a broader look, one that encompasses both copyright doctrine and antitrust process, undermines the conventional wisdom that United States protects copyright more strongly than does the European Union. Zooming out from refusals to deal and examining other facets of copyright and antitrust law reveals that, where innovative competition is at stake, U.S. law has tended to circumscribe copyrights more closely than has EU law, both internally - by contracting the scope of the copyright-and externally-by making antitrust scrutiny widely available.

Our third point seeks to explain why the European Union has relied on competition law to police the anticompetitive use of copyrighted works while the United States has instead relied on doctrines internal to its copyright law to promote innovative competition and restrain copyright overreach. We suggest that differences in institutional structure and antitrust process, as well as different conceptions of copyright law and attitudes toward antitrust enforcement, may help explain the distinct approaches that the European Union and the United States have taken to resolving similar problems.

We limit our attention in this article primarily to the interaction between antitrust law and copyright law. We limit our focus in this manner for two main reasons. First, many of the leading EU cases on the interaction between antitrust law and IPRs have involved subject matter in the domain of copyright. Therefore, the story of the jurisprudential intersection and interaction between antitrust law and IPRs, given American and European case law in their present form, is in large part the story of the interaction between copyright law and antitrust law. Second, a careful examination of the interaction between copyright law and antitrust is itself a substantial undertaking and does not permit us also to examine, in the context of this article, the interaction between antitrust and other IPR regimes, such as patents. We do, however, believe that our analysis of the interaction between copyright and antitrust may shed meaningful, albeit limited, light on the relationship between antitrust and IPRs more generally.

\section{ANTITRUST REGULATION OF IPRS IN THE UNITED STATES AND EUROPE}

Although antitrust law can affect IPRs in a number of ways, this Part focuses specifically on the law of refusals to license IPRs. There are two reasons for this. The first is that antitrust scrutiny of refusals to license IPRs constitutes in some sense the most significant impact that antitrust law can have on IPRs. While other antitrust doctrines-such as those relating to price discrimination, product tying, or horizontal agreements-can also limit the use of IPRs, a finding that a refusal to license an IPR violates antitrust laws has the greatest potential impact on IPRs because it aims at the heart of the IP owner's right to exclude. Such a finding may result in injunctive relief that 
amounts to compulsory licensing of an IPR. Second, as a practical matter, most of the contentious European antitrust decisions dealing with IPRs have dealt with refusals to license copyrighted works, so any comparative discussion of the interface between antitrust and IP must of necessity focus on refusals to deal.

\section{A. The American Approach to Refusals to License}

American courts have been very reluctant to impose positive obligations on parties to deal with their competitors. The high watermark of this reluctance is the Supreme Court's decision in Verizon Communications Inc. v. Law Offices of Curtis V. Trinko. ${ }^{12}$ Although Trinko did not deal with IPRs, it is important to this discussion for two primary reasons. First, Trinko is now the leading case on refusals to deal under Section 2 of the Sherman Act $^{13}$ and provides considerable guidance on the contours of American law on this point. Second, Trinko demonstrates the American courts' general reluctance to impose positive obligations on parties to deal with their competitors, and, a fortiori, it may portend even greater reluctance to impose an obligation to license IPRs, where the policy rationales against compulsory licensing might seem especially strong. ${ }^{14}$

Trinko concerned the failure of Verizon Communications to provide nondiscriminatory access to its telephone network to competing local exchange carriers. The Telecommunications Act required Verizon, the incumbent phone service, to provide non-discriminatory access to its network to competing phone services. Competing service providers alleged that Verizon was violating its obligations under the Act, and, following investigations by the New York Public Service Commission and the Federal Communications Commission, remedial measures were imposed that required Verizon to modify its behavior and provide non-discriminatory network access. A customer of a

\footnotetext{
12540 U.S. 398 (2004).

1315 U.S.C. $\S 2$ ("Every person who shall monopolize, or attempt to monopolize, or combine or conspire with any other person or persons, to monopolize any part of the trade or commerce among the several States, or with foreign nations, shall be deemed guilty of a felony, and, on conviction thereof, shall be punished by fine not exceeding $\$ 100,000,000$ if a corporation, or, if any other person, $\$ 1,000,000$, or by imprisonment not exceeding 10 years, or by both said punishments, in the discretion of the court.").

${ }^{14}$ See, e.g., Richard A. Epstein, The Property Rights Movement and Intellectual Property, Regulation, Winter 2007-2008, at 58, 62 (arguing that weakening a patent holder's right to exclude creates a risk of "systematic under-compensation during the limited life of a patent [that] is likely to reduce the level of innovation while increasing the administrative costs of running the entire system.”). But see Howard A. Shelanski, Unilateral Refusals to Deal in Intellectual and Other Property, 76 Antitrust L.J. 369 (2009) (arguing that antitrust law's willingness to impose liability for refusal to deal should not depend on whether the assset in question is protected by IP or not, and neither theory nor evidence support applying a more stringent standard for refusal to license IP).
} 
competing local phone service provider subsequently brought a class action, alleging that Verizon's refusal to provide adequate network access to its competitors constituted a violation of Section 2 of the Sherman Act. The Supreme Court rejected the plaintiff's claim and refused to find Verizon liable for its refusal to deal.

In doing so, the Supreme Court first noted that, in general, a firm is under no duty to deal with its competitors. ${ }^{15}$ The Court proceeded, however, to address two potential exceptions to this general rule. The first is the so-called Aspen Skiing exception. ${ }^{16}$ This is, as the Court characterized it, a "limited exception" under which a defendant may be held liable for a refusal to deal if it terminates a previously existing, profitable, and voluntary course of dealing with another party to achieve an anticompetitive end. ${ }^{17}$ The hallmark of this exception is a departure from a previous course of dealing; where there are no prior dealings, there can be no liability.

The second potential exception addressed by the Supreme Court relates to the essential facilities doctrine. Although courts sometimes differ in how they articulate the doctrine, ${ }^{18}$ some lower courts have held that the doctrine requires a monopolist to deal with a competitor if the monopolist controls a facility without which the competitor cannot meaningfully compete in the market. In Trinko, however, the Supreme Court noted that it had never either accepted or rejected the essential facilities doctrine, and it declined to express an opinion either way. Instead, the Court simply held that if the doctrine did exist, it would not apply in the instant case. ${ }^{19}$ Thus, the Court in Trinko clearly signaled an intention strictly to limit the circumstances under which a refusal to deal may give rise to antitrust liability.

\footnotetext{
${ }^{15}$ Trinko, 540 U.S. at $407-08$.

${ }^{16}$ Aspen Skiing Co. v. Aspen Highlands Skiing Corp., 472 U.S. 585 (1985). For a more thorough discussion of Aspen Skiing as well as the state of the Aspen Skiing approach following Trinko, see Marina Lao, Aspen Skiing and Trinko: Antitrust Intent and "Sacrifice," 73 ANTITRUST L.J. 171 (2005).

${ }^{17}$ Trinko, 540 U.S. at 409. In addition to calling the Aspen Skiing doctrine a "limited exception," the Court also noted that "Aspen Skiing is at or near the outer boundary of $\S 2$ liability." Id.

${ }^{18}$ The most frequently cited formulation of the essential facilities doctrine in federal antitrust law, which is subject to question after Trinko, is found in MCI Communications Corp. v. AT\&T Co., 708 F.2d 1081 (7th Cir. 1983), where the court outlined four elements to an essential facilities claim: "(1) control of the essential facility by a monopolist; (2) a competitor's inability practically or reasonably to duplicate the essential facility; (3) the denial of the use of the facility to a competitor; and (4) the feasibility of providing the facility." Id. at 1132-33.

${ }^{19}$ Trinko, 540 U.S. at $410-11$. The Court did note that, if the essential facilities doctrine does exist, an "indispensable requirement for invoking the doctrine is the unavailability of access to the 'essential facilities'; where access exists, the doctrine serves no purpose." Id. at 411 . The Court also limited the scope of the essential facilities doctrine by holding that, where a state or federal agency has the power to compel sharing, the essential facilities doctrine cannot apply. Id. at $411-16$.
} 
The Supreme Court reaffirmed this restrictive interpretation of refusal-todeal liability in its 2009 decision in Pacific Bell Telephone Co. v. linkLine Communications Inc. ${ }^{20}$ The plaintiffs in that case were Internet service providers (ISPs) that competed with AT\&T in the retail market for DSL service. The ISPs did not own their own DSL lines. Instead, they leased wholesale DSL transport service from AT\&T, which was bound by the conditions of a prior merger to lease such service to them. The ISPs alleged that AT\&T had sought to "squeeze" them out of the market by keeping too high the wholesale price at which it sold access to its DSL lines to the ISPs while setting too low the retail price at which it sold DSL service to consumers.

A majority of the Supreme Court rejected the possibility of liability under Section 2 of the Sherman Act for "price squeezing." Two points from linkLine are worth noting for our purposes. First, the majority of the Court interpreted Trinko as holding that "if a firm has no antitrust duty to deal with its competitors at wholesale, it certainly has no duty to deal under terms and conditions that the rivals find commercially advantageous." ${ }^{21}$ This interpretation signals intense skepticism among the Court's members toward rules that would police monopolists' pricing decisions. Second, in its brief discussion of the "limited circumstances in which a firm's unilateral refusal to deal with its rivals can give rise to antitrust liability," the Court cited Aspen Skiing, but made no mention of a broader essential facilities doctrine. ${ }^{22}$ Thus, linkLine not only maintains but intensifies Trinko's restrictive attitude toward antitrust claims based on unilateral refusals to deal. Nevertheless, linkLine, like Trinko, stopped short of treating refusals to deal as per se legal or holding that liability is limited to Aspen-type cases. ${ }^{23}$

While the Supreme Court has not recently applied this body of law in the context of IPRs, some (though certainly not all) circuit court decisions in this area confirm that a refusal to deal will very seldom give rise to liability. ${ }^{24}$ The First Circuit's decision in Data General Corp. v. Grumman Systems Support Corp ${ }^{25}$ provides an excellent example. Data General was a manufacturer of minicomputers that also serviced its own computers. While it had a small share of the market for the sale of minicomputers, it held 90 percent of the market for servicing its own computers. Data General developed a software program, ADEX, for diagnosing problems in Data General computers, and it refused to license use of that program to all but a small number of service

\footnotetext{
${ }^{20} 555$ U.S. 438 (2009).

${ }^{21} \mathrm{Id}$. at 450 .

${ }^{22} \mathrm{Id}$. at 448.

${ }^{23}$ Shelanski, supra note 14 , at 377.

${ }^{24} I d$. at 373-78 (detailing the different approaches among the circuits).

2536 F.3d 1147 (1st Cir. 1994), abrogated on other grounds by Reed Elsevier, Inc. v. Muchnick, 559 U.S. 154 (2010).
} 
providers. Grumman ultimately acquired copies of ADEX and made use of the program. Data General brought an action for copyright infringement, and Grumman counterclaimed, alleging that Data General's refusal to license ADEX violated the antitrust laws.

The First Circuit's reasoning with respect to the antitrust counterclaim appears to tightly constrain the possibility of finding antitrust liability for refusal to license a copyrighted work. The court noted that, while a monopolist's refusal to deal could count as prima facie evidence of exclusionary conduct that could give rise to liability under Section 2 of the Sherman Act, the monopolist could rebut this evidence by establishing a valid business justification for its refusal to deal. Most important for our purposes, the First Circuit held that "an author's desire to exclude others from use of its copyrighted work is a presumptively valid business justification for any immediate harm to consumers." ${ }^{26}$ By making the desire to exclude itself a presumptively valid justification for the refusal to deal, the First Circuit placed a significant burden on those wishing to challenge refusals to license copyrighted works. Other courts have since adopted the same approach, further evincing the tendency of American courts to restrict antitrust scrutiny of refusals to license. ${ }^{27}$ The Federal Circuit has gone even further and held that, subject to certain enumerated exceptions, a refusal to license an IPR cannot give rise to antitrust liability. ${ }^{28}$

\section{B. The European Approach to Refusals to License}

Unlike their American counterparts, European institutions have expressed a greater willingness to use antitrust law to force firms to license their IPRs. While European authorities have given primacy to intellectual property rights in a number of cases, in three cases, the European Commission and the EU courts have found that a refusal to license constituted an abuse of dominance

\footnotetext{
${ }^{26} I d$. at 1187.

${ }^{27}$ The Ninth Circuit accepted a modified formulation of the Data General approach in Image Technical Services, Inc. v. Eastman Kodak Co., 125 F.3d 1195, 1218 (9th Cir. 1997), one of the few cases in which a circuit court found that a refusal to license IPRs violated Section 2 of the Sherman Act. In that case, the court held that the plaintiff independent service organizations (ISOs) had rebutted the presumption that the protection of IPRs is a valid justification, as the evidence suggested that Kodak's motivation for refusing to license its IPRs was not a desire to protect its IPRs, but rather a desire to exclude competition from the service market. (Note that the Federal Circuit decision discussed in the text expressly disagreed with the Ninth Circuit on this point. See infra note 28.) For enlightening commentary on these decisions, see R. Hewitt Pate, Refusals to Deal and Intellectual Property Rights, 10 Geo. Mason L. Rev. 429 (2002).

${ }^{28}$ In re Independent Serv. Org. Antitrust Litig., 203 F.3d 1322 (Fed. Cir. 2000). In that case, Xerox refused to sell patented parts and copyrighted manuals to ISOs. The Federal Circuit expressly "decline[d] to follow [the Ninth Circuit in] Image Technical Services." Id. at 1327; see also discussion supra note 27.
} 
under what is now Article 102 of the Treaty on the Functioning of The European Union (TFEU). ${ }^{29}$

The first of these cases is the Magill case. ${ }^{30}$ There, three television stations-RTE, ITV, and BBC-each published a TV guide covering exclusively its own programs. Each claimed copyright protection, under UK and Irish law, for its own weekly program listings. Magill attempted to publish a comprehensive weekly television guide, in competition with the separate guides published by each station, but the three copyright owners prevented it from doing so. Magill lodged a complaint with the European Commission, which found the refusal to be an abuse of dominant position and ordered a compulsory license of copyright on TV listings. ${ }^{31}$ Both the European Court of First Instance $(\mathrm{CFI})^{32}$ and the European Court of Justice (ECJ) ${ }^{33}$ upheld the decision.

In its decision, the ECJ outlined a number of pertinent principles as to when a refusal to license copyrighted works will constitute an abuse of dominance. It first acknowledged that the mere refusal to license a copyrighted work, even if done by a firm with a dominant position in the market, will not constitute an abuse of dominance. ${ }^{34}$ It then noted, however, that such a refusal could constitute an abuse of dominance in "exceptional circumstances." 35 The ECJ proceeded to conclude that the television stations had abused their dominant position based on three factors. First, the refusal to license the copyrighted works prevented the emergence of a new product, a comprehensive listing of television programs, thereby bringing the firms' actions into the ambit of what is now subheading (b) of the second paragraph of Article 102 TFEU. ${ }^{36}$ Second, there was no objective justification for the refusal to license. ${ }^{37}$ Third, the refusal, by denying competitors information necessary to compete in the tele-

${ }^{29}$ Treaty on the Functioning of the European Union art. 102, Sept. 5, 2008, 2008 O.J. (C 115) 47 (effective Dec. 1, 2009) [hereinafter TFEU].

30 Joined Cases C-241/91 P \& C-242/91 P, Radio Telefis Eireann (RTE) \& Indep. Television Publ'ns Ltd (ITP) v. Comm'n (Magill), 1995 E.C.R. I-743.

78) 43 .

${ }^{32}$ Case T-69/89, Radio Telefis Eireann v. Comm'n, 1991 E.C.R. II-485.

${ }^{33}$ Magill, 1995 E.C.R. I-743 (Judgment of the Court at I-808).

${ }^{34}$ Id. II 49 (Judgment of the Court at I-823).

${ }^{35} \mathrm{Id}$. II 50.

${ }^{36}$ Id. II 54 (Judgment of the Court at I-824); see TFEU, supra note 29 ("Any abuse by one or more undertakings of a dominant position within the internal market or in a substantial part of it shall be prohibited as incompatible with the internal market in so far as it may affect trade between Member States. Such abuse may, in particular, consist in .... (b) limiting production, markets or technical development to the prejudice of consumers . ...").

${ }^{37}$ Magill, 1995 E.C.R. I-743, II 55 (Judgment of the Court at I-824). 
vision-listings market, had the effect of foreclosing competition in that market. $^{38}$

The second case in which European courts found that a refusal to license copyrighted works could constitute an abuse of dominance was the IMS Health case. ${ }^{39}$ IMS Health tracked sales of pharmaceutical products in Germany. To present this data effectively, it created, in cooperation with the pharmaceutical industry, a structure consisting of 1860 "bricks" that represented particular geographical areas of Germany. This structure rapidly became the standard mechanism by which pharmaceutical information was marketed and sold, and clients were resistant to alternative brick structures developed by NDC Health, a competitor. NDC Health ultimately used a brick structure very similar to the one developed by IMS Health, and IMS Health brought an action for copyright infringement in the German courts.

The case thereafter became procedurally complex. IMS Health was initially successful in German courts in obtaining interlocutory injunctions preventing NDC Health from using its brick structure. NDC Health then lodged a complaint with the European Commission that IMS Health's conduct was abusive within the meaning of Article 82 (now Article 102 TFEU). The European Commission initially ordered IMS Health, as an interim measure, to license the use of its brick structure to NDC Health. ${ }^{40}$ This order was eventually overturned by higher courts, pending a determination of the case on its merits. ${ }^{41}$ While the European Commission's case against IMS was proceeding, however, the Landgericht Frankfurt am Main, the German court adjudicating the merits of IMS's copyright infringement claim, decided that IMS could not obtain injunctive relief to protect its rights if it was exercising those rights in an abusive manner. It thus decided to stay the copyright-infringement proceedings and refer questions to the European Court of Justice relating to the proper interpretation of Article 82 as it applied to the case.

In reaching its decision, the ECJ summarized existing case law on when the refusal to license an IPR could constitute an abuse of dominance:

[I]n order for the refusal by an undertaking which owns a copyright to give access to a product or service indispensable for carrying on a particular business to be treated as abusive, it is sufficient that three cumulative conditions be satisfied, namely, that that refusal is preventing the emergence of a new

\footnotetext{
${ }^{38} I d$. II 56.

${ }^{39}$ Case C-418/01, IMS Health GmbH \& Co. OHG v. NDC Health GmbH \& Co. KG, 2004 E.C.R. I-5039.

${ }^{40}$ Case COMP/D3/38.044-NDC Health/IMS Health, Comm'n Decision, 2002 O.J. (L 59) 18, II 215 (Interim Measures).

${ }^{41}$ Case T-184/01R, IMS Health Inc. v. Comm'n, 2001 E.C.R. II-3193, aff'd, Case C-481/01, P(R) NDC Health Corp. v. IMS Health Inc. \& Comm'n, 2002 E.C.R. I-3401.
} 
product for which there is a potential consumer demand, that it is unjustified and such as to exclude any competition on a secondary market. ${ }^{42}$

The ECJ thus restated the general structure of the test from Magill, emphasizing that a refusal to license an IPR can be abusive only when it prevents the emergence of a new product in the secondary market. The ECJ stated that this requirement would not be satisfied if the refusal were merely to prevent competitors from offering duplicates of the products that the IPR owner already offered on the secondary market. ${ }^{43}$ The ECJ viewed this requirement as manifesting and ensuring a fair balance between the protection of IPRs and the public interest in competitive markets. ${ }^{44}$ Having outlined the applicable legal principles, the ECJ left it to the German court to apply those principles to the facts of the case. ${ }^{45}$ While the ECJ thus did not itself compel IMS to license its brick structure, it provided the German court with a significant scope to find that IMS's conduct did indeed constitute an abuse of dominance.

The most recent, and undoubtedly the most contentious, decision by European authorities to order the compulsory licensing of copyrighted works was the Microsoft case. ${ }^{46}$ That case dealt with, among other things, Microsoft's alleged failure to provide to competitors sufficient interoperability information relating to its workgroup server operating system. The European Commission found that Microsoft's failure to disclose such information to competing software developers violated Article 82 of the Treaty of Rome, and the CFI upheld that finding. ${ }^{47}$

\footnotetext{
${ }^{42}$ IMS Health, 2004 E.C.R. I-5039, II 38 (Judgment of the Court).

${ }^{43}$ Id. II 49.

${ }^{44} I d$. II 48 (" $[I]$ n the balancing of the interest in protection of the intellectual property right and the economic freedom of its owner against the interest in protection of free competition, the latter can prevail only where refusal to grant a licence prevents the development of the secondary market to the detriment of consumers.").

Commentators have generally applauded the "new product" requirement as a necessary condition for the application of the essential facilities doctrine on similar grounds, often proposing relatively minor modifications to the condition to better attain an appropriate balance between antitrust and IP. See, e.g., Christian Ahlborn, David S. Evans \& A. Jorge Padilla, The Logic \& Limits of the "Exceptional Circumstances Test" in Magill and IMS Health, 28 FordHAM INT'L L.J. 1109 (2005); Daryl Lim, Copyright Under Siege: An Economic Analysis of the Essential Facilities Doctrine and the Compulsory Licensing of Copyrighted Works, 17 ALB. L.J. SCI. \& ТЕСH. 481, 532-34 (2007).

${ }^{45}$ The German court ultimately resolved the case on copyright grounds, and the European Commission, satisfied with the result, halted its own inquiry into the matter. See Czapracka, supra note 3 , at 86 n.208.

${ }^{46}$ Case COMP/C-3/37.792-Microsoft Corp., Comm'n Decision (Mar. 24, 2004) (summary at 2007 O.J. (L 32) 23), aff'd, Case T-201/04, Microsoft Corp. v. Comm'n, 2007 E.C.R. II-3601. For scathing criticism of the Court of First Instance decision in Microsoft, see Spulber, supra note 7. For more balanced commentary on the Commission's decision, see Lévêque, supra note 9 .

${ }^{47}$ Case COMP/C-3/37.792-Microsoft Corp., Comm'n Decision, 2007 O.J. (L 32) 23, aff'd,
} Case T-201/04, Microsoft Corp. v. Comm'n, 2007 E.C.R. II-3601. 
In its decision, the CFI purported to restate principles from earlier European jurisprudence. ${ }^{48}$ In some respects, however, the CFI expanded the ambit of Article 82 as a means of regulating the use of IPRs. First, the CFI substantially relaxed the requirement in earlier case law that the refusal to license an IPR must prevent the emergence of a new product for which there is consumer demand. ${ }^{49}$ Rather, the CFI suggested that the underlying analysis considers whether the refusal to deal causes "prejudice to consumers," and it indicated that the limitation of "technical development" could also cause such prejudice. ${ }^{50}$ Arguably, this lower standard can be satisfied in any circumstance where the licensing of the IPR will not simply result in a competitor creating a copy of the IP owner's product.

Second, the CFI spelled out a position that had remained implicit in previous case law. In contrast to the American approach under Data General, the CFI held that the mere protection of intellectual property rights cannot constitute an objective justification for a refusal to license. ${ }^{51}$ This holding, together with the CFI's evisceration of the new product requirement that earlier case law had regarded as critical to the balance between IPRs and antitrust, seems to indicate a preference for competitive market structures over the protection of IPRs where the two conflict.

\section{Comparing the Approaches: A Doctrinal Divergence}

The above exposition demonstrates that EU courts are more willing than their American counterparts to find that a refusal to license an IPR can constitute an antitrust violation. While liability for refusal to deal stands on very tenuous ground in the United States, it is firmly established in European jurisprudence and has been used to compel the licensing of IPRs on a number of occasions. Additionally, even when applying the narrow exceptions to the U.S. no-liability rule, American courts have held that merely controlling an IPR is a presumptively legitimate business justification for not licensing that IPR, while European courts have firmly rejected this position.

Though these differences are important, it is equally important not to overstate the divergence between European and American approaches to the regulation of IPRs using antitrust law. Both jurisdictions accept that the refusal to license an IPR, even by a dominant firm, does not by itself constitute an abuse of dominance, and despite European decisions that exemplify a more activist

\footnotetext{
${ }^{48}$ Microsoft, 2007 E.C.R. II-3601, IIII 319-336 (citing, inter alia, Magill and IMS Health).

${ }^{49} \mathrm{Id}$. II 647 ("The circumstance relating to the appearance of a new product, as envisaged in Magill and IMS Health . . . cannot be the only parameter which determines whether a refusal to license an intellectual property right is capable of causing prejudice to consumers within the meaning of Article 82(b) EC.”).

${ }^{50} \mathrm{Id}$.

${ }^{51} I d$. II 690.
} 
antitrust approach, European authorities have in a number of cases declined to find that a refusal to license an IPR (or other asset) constituted an abuse of dominance. ${ }^{52}$ Additionally, while the Microsoft case seemingly represents a high point in the application of Article 82 (now 102 TFEU) to IPRs, a plausible argument can be made that it would have been decided similarly under American law.

One argument advanced by the Commission for imposing liability on Microsoft was that it had disrupted previous levels of supply of interoperability information; the Commission alleged that Microsoft had earlier disclosed such information and had only stopped disclosing such information when its own product had achieved a reasonably strong position in the marketplace. ${ }^{53}$ If this allegation were true, then liability arguably could have been found in the United States under the Aspen Skiing exception. Moreover, the European Microsoft antitrust litigation followed on the heels of related U.S. litigation that ultimately resulted in a settlement that, among other remedies, compelled Microsoft to disclose interoperability information to competitors. ${ }^{54}$ Therefore, it is important not to overstate the extent to which the decisions by the Commission and the Court of First Instance depart from U.S. antitrust principles. Indeed, mandatory disclosure of interoperability information is not an uncommon remedy in U.S. antitrust law..$^{55}$

\footnotetext{
52 See, e.g., Case 238/87, AB Volvo v. Erik Veng (UK) Ltd., 1988 E.C.R. 6211, II 8 (Judgment of the Court) ("It must also be emphasized that the right of the proprietor of a protected design to prevent third parties from manufacturing and selling or importing, without its consent, products incorporating the design constitutes the very subject-matter of his exclusive right. It follows that an obligation imposed upon the proprietor of a protected design to grant to third parties, even in return for a reasonable royalty, a licence for the supply of products incorporating the design would lead to the proprietor thereof being deprived of the substance of his exclusive right, and that a refusal to grant such a licence cannot in itself constitute an abuse of a dominant position."); see also Case T-504/93, Tiercé Ladbroke SA v. Comm'n, 1997 E.C.R. II-923 (finding that the refusal by a French organizer of off-course betting in France to license the use of sounds and pictures of French races to Ladbroke, the largest owner of betting shops in Belgium, did not amount to abuse of dominance); Case C-7/97, Oscar Bronner GmbH \& Co. KG v. Mediaprint Zeitungs- und Zeitschriftenverlag GmbH \& Co. KG, 1998 E.C.R. I-7791 (holding that Mediaprint, a large newspaper publisher and operator of a home delivery scheme did not abuse its dominant position when it refused to let Oscar Bronner, the publisher of a small newspaper, to use Mediaprint's distribution scheme).

${ }^{53}$ Microsoft, 2007 E.C.R. II-3601, IIII 307-308.

${ }^{54}$ For the approval of the settlement, see United States v. Microsoft Corp., 231 F. Supp. $2 \mathrm{~d}$ 144 (D.D.C. 2002). For background on the litigation, see United States v. Microsoft Corp., 253 F.3d 34 (D.C. Cir. 2001).

55 Aaron K. Perzanowski, Rethinking Anticircumvention's Interoperability Policy, 42 U.C. DAvis L. Rev. 1549, 1597 (2009) ("The mandatory disclosure of interoperability information is not an uncommon antitrust remedy. U.S. antitrust authorities, and their European counterparts, have required parties to license or disclose information to enable the development of competing and interoperable products.").
} 
Similarly, there are reasons to suspect that Trinko does not present a clear statement of U.S. law on refusals to deal. Trinko's apparent hands-off approach to refusals to deal may in fact reflect a number of idiosyncratic weaknesses in the plaintiff's case, weaknesses that might serve to distinguish Trinko from future cases challenging refusals to deal. For instance, three of the nine justices declined to address the merits of the refusal to deal claim, holding instead that the plaintiff did not have the standing required by U.S. antitrust law to advance its claim. ${ }^{56}$ Additionally, the majority decision focused heavily on the presence of a statutory mechanism for regulating Verizon's conduct, a mechanism that could have been and was in fact utilized, and that thereby lessened the need for antitrust regulation of the refusal to deal. ${ }^{57}$ Thus, the doctrinal discussion in the majority opinion may reflect the overall weakness of the plaintiff's case, more than it presents a clear articulation of the law as it would apply in a more difficult case. Accordingly, the implications of Trinko are not yet fully clear. ${ }^{58}$

Finally, the differences between EU and U.S. law on refusal to license IPRs should not be overstated because the small number of decided cases involving refusals to license IPRs makes it difficult to draw meaningful conclusions on the precise contours of IPR owners' obligation to license their IPRs. It may be too early to know whether the European decisions reflect core principles of EU law or whether they will eventually be regarded as outliers, similar to such U.S. cases as Kodak ${ }^{59}$ that should be understood in light of their unique contexts. ${ }^{60}$ While we accept the view that current U.S. and EU antitrust regulation of IPRs seems to diverge, it may be too early to determine whether that divergence lies at the core or at the margins of competition law.

\footnotetext{
56 Verizon Commc'ns Inc. v. Law Offices of Curtis V. Trinko, 540 U.S. 398, 416-17 (2004) (Stevens, J., concurring).

${ }^{57} \mathrm{Id}$. at $411-16$.

${ }^{58}$ For commentary on Trinko, as well as differing views on its legal implications, see, for example, Michael A. Carrier, Refusals to License Intellectual Property After Trinko, 55 DEPAUL L. REv. 1191 (2006) (discussing the implications of Trinko for refusals to license IPRs); Edward D. Cavanagh, Trinko: A Kinder, Gentler Approach to Dominant Firms Under the Antitrust Laws?, 59 Me. L. Rev. 112, 114 (2007) (noting that lower courts have been somewhat reluctant to fully embrace the restrictive approach outlined in Trinko to refusals to deal under Section 2 of the Sherman Act and suggesting that rather than marking an abrupt departure from prior cases, Trinko underscores the ambiguity of the law on non-price exclusionary behavior); Frank $\mathrm{X}$. Schoen, Exclusionary Conduct After Trinko, 80 N.Y.U. L. Rev. 1625 (2005) (arguing for a relatively narrow application of the holding in Trinko).

${ }^{59}$ Image Technical Servs., Inc. v. Eastman Kodak Co., 125 F.3d 1195, 1218 (9th Cir. 1997).

${ }^{60}$ For example, lack of harmonization of national copyright law might have prevented EU law from adopting IP solutions and left competition law as the only tool at the Commission's disposal. See infra Part II.A.
} 


\section{THE STRENGTH OF COPYRIGHT PROTECTION: A TRANSATLANTIC COMPARISON}

The previous Part confirmed the conventional wisdom that European courts are more willing than are American courts to use antitrust doctrines to limit IPRs. We now address the view in the relevant literature that this divergence runs much deeper, into the basic approaches of the two legal regimes to competition, innovation, and regulation. According to some, a case like Magill represents a fundamental hostility towards IPRs by EU institutions, one that can be traced back to the influence of the Freiburg Ordoliberal School of economics and its aversion to any kind of monopolistic market structure. ${ }^{61}$ Others maintain that the EU position favors short-term benefits to allocative efficiency from increased competition at the expense of long-term innovation (dynamic efficiency). ${ }^{62}$ They contend that the EU position understates the importance of Schumpeterian competition "for" the market, while overstating the virtues of competition "within" the market. ${ }^{63}$

In our opinion, it is difficult to reach broad conclusions about fundamental differences between the United States and the European Union on the basis of differences in one particular legal doctrine. Even though EU competition law seems to have adopted a more aggressive stance towards refusals to license

\footnotetext{
${ }^{61}$ Valentine Korah, The Interface Between Intellectual Property and Antitrust: The European Experience, 69 Antitrust L.J. 801, 803 (2001).

${ }^{62}$ See Alan Devlin \& Michael Jacobs, Microsoft's Five Fatal Flaws, 2009 Colum. Bus. L. REv. 67, 71 (2009) ("Microsoft marks an ominous shift in Europe's jurisprudential thinking, revealing in particular an unequivocal embrace of short-run consumer wealth at the possible expense of long-run innovation."); Reichenberger, supra note 3, at 564 (arguing that the EU approach favored competition and market integration goals over IPRs without sufficiently considering the possible effects on national IP regimes, the resulting lessening of incentives to innovate, and the consequences of letting courts become central planners of sharing agreements); James Turney, Defining the Limits of the EU Essential Facilities Doctrine on Intellectual Property Rights: The Primacy of Securing Optimal Innovation, 3 Nw. J. Tech. \& Intell. Prop. 179, 197 (2005) (arguing that the evils of a monopoly must be considered in the context of innovation and that the essential facilities doctrine, in attributing too much weight to short-term interests, is likely to punish the most important innovation).

${ }^{63}$ See Josef Drexl, Abuse of Dominance in Licensing and Refusal to License: A "More Economic Approach" to Competition by Imitation and to Competition by Substitution, in EuROPEAN Competition Law Annual 2005: The Interaction Between Competition Law and IntelLeCtual Property Law 647 (Claus-Dieter Ehlermann \& Isabela Atanasiu eds., 2007) (arguing that where IPRs make "competition by substitution" impossible, any obligations imposed on IPR holders should not distort competition for the market); David Howarth \& Kathryn McMahon, "Windows Has Performed an Illegal Operation": The Court of First Instance's Judgment in Microsoft v. Commission, 29 Eur. Competition L. Rev. 117, 120-22 (2008) (arguing that Microsoft's market share could be explained by a variety of factors unrelated to anticompetitive behavior; that courts should decline to intervene in such cases to avoid possible Type I errors; and that competition law is a blunt instrument to deal with the complexities of Schumpeterian markets); Turney, supra note 62, at 183 (arguing that there will naturally be market concentration in high-tech markets, and that a policy of opening markets to competitors making similar products ignores the benefits of Schumpeterian competition, as well as the benefits that consumers derive from network effects).
} 
IPRs, that stance tells us very little about each jurisdiction's overall approach toward the roles of IPRs and antitrust law in promoting innovation and consumer welfare.

In assessing a jurisdiction's balance between antitrust law and the protection of IPRs, it is necessary to analyze both bodies of law comprehensively. Identifying circumstances under which antitrust law may compel the licensing of a particular IPR is only part of the analysis. One must also consider the subject matter that the IPR protects and the extent to which IP law entitles the IP owner to exclude others from using the IP. If IP laws do not protect the subject matter in question, or if an exception or limitation to the IPR would permit another person to use it without the IP owner's permission, then no need for antitrust intervention arises; other firms can make use of the subject matter even without the benefit of an antitrust-based compulsory license. In other words, (a) not recognizing an IPR, and (b) recognizing the IPR but compelling it to be licensed through antitrust law are functionally similar options.

This is not to say that the two alternatives are perfect, or even near perfect, substitutes. For example, the first entails no license fees, whereas the second might contemplate the payment of a reasonable fee. There are also important procedural differences that will be discussed below in Part IV. Thus, before reaching any conclusion about a jurisdiction's overall attitude to IPRs, it is necessary to consider not only the application of antitrust principles to IPRs, but also the extent to which the IP regimes of the respective jurisdictions limit the scope or exercise of IPRs for the purpose (or with the effect) of advancing competitive ends from within.

While a few commentators have already observed that the European decisions may be seen as a reaction by the institutions of the European Union to some over-protective copyright rules of individual member states, ${ }^{64}$ we suggest that the difference in the underlying IP regimes stems from a more systemic procompetitive bent of U.S. IP law-and copyright law in particularthat currently has no equivalent in Europe. ${ }^{65}$ To use Thomas Cotter's phrase, it appears that American copyright law embodies a stronger procompetitive in-

\footnotetext{
${ }^{64}$ See, e.g., Mark A. Lemley, A New Balance Between IP and Antitrust, 13 Sw. J.L. \& Trade Aм. 237, 256 n.59 (2007); Aaron K. Perzanowski, supra note 55, at 1608.

${ }^{65} \mathrm{~A}$ few other commentators have written about the relative weakness of U.S. copyright law. See, e.g., Paul J. Heald, American Corporate Copyright: A Brilliant, Uncoordinated Plan, 12 J. Intell. Prop. L. 489 (2005); see also Howard Knopf, The Annual "301" Show-USTR Calls for Comment-21 Reasons Why Canadian Copyright Law Is Already Stronger than USA's, ExCEss Copyright Blog (Feb. 17, 2010), http://excesscopyright.blogspot.com/2010/02/annual-301parade-ustr-calls-for.html.
} 
terest, ${ }^{66}$ the presence of which lessens the need for rigorous antitrust scrutiny of copyright holders' behavior. ${ }^{67}$

In presenting this argument, we look at four distinct areas of European and American copyright law. We consider first the treatment of facts and factual compilations under European and American copyright law. We show that had the Magill case been litigated in the United States, the U.S. courts might have reached a similar, and arguably more radical, result, but they likely would have done so on copyright rather than on antitrust grounds. We then consider three copyright doctrines-the merger, copyright misuse, and fair use doctrines-and argue that they have been applied to promote innovative competition and to limit or preclude the anti-competitive reliance on copyright. These copyright doctrines have thereby obviated or reduced the need for robust antitrust doctrines to prevent such anticompetitive uses.

\section{A. Facts and Factual Compilations}

American and European copyright laws treat factual compilations in a somewhat similar fashion. While neither protects facts alone, both may protect compilations of facts. Nonetheless, considerable differences exist with respect to both the standard under which copyright in a compilation shall subsist, as well as the extent to which third parties can freely copy the facts from a protected compilation. This differential treatment demonstrates how a similar procompetitive outcome can be achieved either by calibrating the scope of IPRs from within or by using antitrust law to limit their practical reach from without.

Turning first to American jurisprudence, it is clear that the United States grants more limited protection under copyright law to factual compilations than do European jurisdictions. The leading decision by the U.S. Supreme Court is Feist Publications v. Rural Telephone Service, which concerned the scope of copyright protection in the listings in a phone directory. ${ }^{68}$ Rural Tele-

\footnotetext{
66 Thomas F. Cotter, The Procompetitive Interest in Intellectual Property Law, 48 Wм. \& MARY L. Rev. 483, 487 (2006) ("On occasion, IP law condemns conduct on the part of IP owners - or excuses otherwise infringing activity on the part of IP defendants-for the express purpose of promoting competition. It does so even though antitrust law-if it were to apply at all - typically would not condemn similar conduct on the part of the IP owner, or require the IP defendant be given free access, absent thorough analysis of (1) the markets within which the parties compete, and (2) whether the IP owner possesses market power.").

${ }^{67} \mathrm{We}$ note that U.S. trademark law may likewise embody procompetitive interests that are largely absent from EU trademark law, and that, as both Shubha Ghosh and Hill Wellford observed, recent U.S. Supreme Court decisions in patent law may reflect a similar procompetitive shift in patent law. See Shubha Ghosh, Carte Blanche, Quanta, and Competition Policy, $34 \mathrm{~J}$. Corp. L. 1209 (2009); Hill B. Wellford, Is the Supreme Court Importing Antitrust Economics into Patent Law? A Different Look at eBay, MedImmune, KSR, and Quanta Computer, GlobaL Competition Pol'y, Summer 2009, Vol. 8, No. 2 (posted online Mar. 2009).

${ }^{68}$ Feist Publ'ns, Inc. v. Rural Tel. Serv. Co., 499 U.S. 340 (1991).
} 
phone Service was the exclusive provider of local phone service in part of Kansas. It was subject to a state regulation that required all telephone companies operating in Kansas to issue annually an updated telephone directory. Accordingly, as a condition of its monopoly franchise, it published a typical telephone directory, consisting of white pages and yellow pages containing the listings within its geographic area. ${ }^{69}$

Feist, an independent publisher, sought to publish a comprehensive phone directory, covering a much larger geographical area. Feist's directory, which would contain the listings of 11 different telephone service areas in 15 counties, would reduce the need to call directory assistance or consult multiple directories. Feist approached each of the 11 telephone services and offered to pay for the right to use its white-pages listings. Of the 11 telephone companies, only Rural refused to license its listings to Feist. ${ }^{70}$ Feist then copied Rural's directory, which prompted Rural to sue Feist for copyright infringement. In addition to defending on copyright grounds, Feist counterclaimed, alleging that Rural's refusal to license its listings violated Section 2 of the Sherman Act and that this antitrust violation also turned Rural's refusal to license its copyright into copyright misuse.

The district court found that the white pages of a telephone directory constitute an original work of authorship and are, therefore, copyrightable, and, consequently, that Feist could not copy the listings. ${ }^{71}$ It rejected Feist's fair use defense ${ }^{72}$ and held that Rural's alleged antitrust violations could not in law constitute copyright misuse. ${ }^{73}$ The court of appeals affirmed, ${ }^{74}$ but the $\mathrm{Su}$ preme Court, in a unanimous decision, reversed. The Supreme Court ultimately held that Rural had no copyright in its phone directory. It held that for copyright to be granted in a work, the work must be "original to the author" in the sense that it possesses at least a "minimal degree of creativity." 75 Because the phone listings were facts that Rural had simply listed in alphabetical order, there was no creativity in the compilation, and thus no copyright. As a result, Feist could copy the listings without fear of liability. It should be emphasized, moreover, that Feist was not the only party entitled to copy the listings; nor was publication of a comprehensive directory the only purpose for which the listings could be copied. The data was free for all: free as in free speech (no prior authorization is required) as well as in free beer (no payment is re-

\footnotetext{
${ }^{69} \mathrm{Id}$. at 342 .

${ }^{70} \mathrm{Id}$. at 343.

${ }^{71}$ Rural Tel. Serv. Co. v. Feist Publ'ns, Inc., 663 F. Supp. 214, 218 (D. Kan. 1987).

${ }^{72} \mathrm{Id}$. at 219.

${ }^{73} \mathrm{Id}$. at 220 (recognizing that an antitrust violation might constitute a patent misuse, but refusing to extend the doctrine to the area of copyright).

${ }^{74}$ Rural Tel. Serv. Co. v. Feist Publ'ns, Inc., 916 F.2d 718 (10th Cir. 1990).

${ }^{75}$ Feist, 499 U.S. at 345.
} 
quired). ${ }^{76}$ Furthermore, even if there were copyright in the compilation, it would not extend to the data itself; the copyright would be "thin," meaning that anybody would be free to copy the non-protected data. ${ }^{77}$

The district court was more sympathetic to Feist, however, when it turned to the antitrust counterclaim. Relying on the essential facilities doctrine, the district court held that Rural's refusal to license its white pages listings was an illegal refusal to deal under the Sherman Act. ${ }^{78}$ It awarded Feist treble damages of $\$ 99,000$ and reasonable attorney's fees, as well as an injunction prohibiting Rural from refusing to license its white pages listings at a reasonable rate. The circuit court reversed on the basis that Feist had not demonstrated that Rural's refusal to license had any anticompetitive effects. ${ }^{79}$ This holding was probably correct, but only in a very technical sense. Rural's refusal to license did not exclude Feist from publishing its comprehensive directory because Feist ignored Rural's ownership claims and copied the listings despite Rural's refusal to license them. Moreover, by the time the circuit court issued its decision on the antitrust claim, the Supreme Court had already ruled that Feist could copy the listings and that Rural had no copyright that could exclude Feist.

The similarity between the facts in Feist and Magill ${ }^{80}$ highlights their very different approaches to a similar legal problem. Both cases involved statutorily franchised companies that refused to license a competitor to use purely factual information that they produced as a secondary product of their primary business. In both cases, the refusal was calculated to stifle the production and marketing of a competing product. In both cases, an independent publisher sought to publish a comprehensive guide, copied the information without permission after its request for a license was denied, and was sued for copyright infringement. In both cases, the defendant-publisher not only defended on copyright grounds, but also brought an antitrust claim (filing an antitrust counterclaim in the United States, and lodging a competition law complaint

\footnotetext{
76 The distinction is often attributed to Richard Stallman. See SAM Williams, Free as IN Freedom: Richard Stallman's Crusade for Free Software 131 (2002); see also Peter Suber, Open Access $\$ 3.3$, at 65-75 (2012) (noting the distinction between gratis and libre, used in the context of open source software and open access publications; gratis denotes the lack of price barriers to access, whereas libre denotes lack of permission restrictions).

77 Feist, 499 U.S. at 349.

${ }^{78}$ Rural Tel. Serv. Co. v. Feist Publ'ns, Inc., 737 F. Supp. 610 (D. Kan. 1990).

${ }^{79}$ Rural Tel. Serv. Co., Inc. v. Feist Publ'ns, Inc., 957 F.2d 765 (10th Cir. 1992). The court held that Feist failed to demonstrate that it suffered any harm to its yellow pages advertising business, that anyone complained about the incompleteness of its directory as a consequence of Rural's refusal to license, or that Rural's actions reduced competition in the yellow pages advertising market. Id. at 769. As Shelanksi notes, by reversing for failure to demonstrate anticompetitive harm, the Tenth Circuit endorsed the idea that a refusal to license could give rise to antitrust liability if it demonstrably led to such harm. Shelanski, supra note 14, at 374.

${ }^{80}$ See supra Part I.B (The European Approach to Refusals to License) and note 30.
} 
with the EC in Europe). In both cases, lower courts ruled in favor of the copyright plaintiff, only to have the highest court ultimately grant the defendant access to the data. In Europe, this result was reached through stronger antitrust laws; in America through weaker copyright laws.

Some commentators have suggested that the ECJ's willingness in the $M a$ gill case to compel the licensing of the television listings stemmed, at least in part, from the Court's view that idiosyncratic national legislation had granted copyright protection to works that did not merit such protection. ${ }^{81}$ If so, the result in Magill may indicate that copyright and antitrust law are two alternative means of achieving a similar competitive outcome, and that the American and European legal systems have chosen different methods of achieving that outcome: while the United States refused to recognize any copyright in a garden-variety compilation of data, EU institutions, lacking jurisdiction over the scope of copyright protection granted under national laws, achieved the same result through antitrust law. ${ }^{82}$ Nevertheless, that conclusion oversimplifies the issue and fails to appreciate how remarkable the U.S. Supreme Court decision in Feist actually was-how genuinely radical it was in the context of the IPantitrust interface.

\footnotetext{
${ }^{81}$ See Czapracka, supra note 3; Donna M. Gitter, The Conflict in the European Community Between Competition Law and Intellectual Property Rights: A Call for Legislative Clarification of the Essential Facilities Doctrine, 40 Aм. Bus. L.J. 217, 252-54 (2003); Turney, supra note 62, at 193-96; Lim, supra note 44, at 530-32 (arguing against the use of the essential facilities doctrine as a means of distinguishing between "meritorious" and "unmeritorious" copyright).

Even if the protection of compilations of the type at issue in Magill may have been an idiosyncrasy of particular national copyright regimes, the European Union's Database Directive has subsequently mandated the creation of additional rights for compilations in the form of the sui generis database right. Council Directive 96/9/EC, On the Legal Protection of Databases, 1996 O.J. (L 77) 20. Indeed, this Directive, which creates certain rights that have no analogue under American law, gave rise to the controversy in IMS Health; the German statutory provisions under which IMS claimed protection for its brick structure were enacted in response to the EU Database Directive. See Case COMP/D3/38.044-NDC Health/IMS Health, Comm'n Decision, 2002 O.J. (L 59) 18 (Interim Measures), II 36. IMS Health presents a slightly different factual scenario than either Feist or Magill, as the IPR that IMS Health sought to protect was the particular structure of its database rather than the factual information within that database. We posit no direct analogy between IMS Health and either Feist or Magill in this section, and we will discuss the resolution of Feist under American copyright law in more detail below. At this point, we only wish to highlight that, with respect to compilations and databases, EU copyright law provided stronger protections to creators of such works than did American copyright law.

${ }^{82}$ Over time, several EU directives have attempted to harmonize certain aspects of the member states' national copyright regimes. See, e.g., Council Directive 91/250/EEC, On the Legal Protection of Computer Programs, 1991 O.J. (L 122) 42, replaced by Council Directive 2009/24/ EC, On the Legal Protection of Computer Programs, 2009 O.J. (L 111) 16; Council Directive 93/ 98/EEC, Harmonizing the Term of Protection for Copyright and Certain Related Rights, 1993 O.J. (L 290) 9; Council Directive 96/9/EC, supra note 81; Council Directive 2001/29/EC, On the Harmonisation of Certain Aspects of Copyright and Related Rights in the Information Society, 2001 O.J. (L 167) 10.
} 
While the European institutions, confronted with a situation that they perceived as requiring intervention, had only one tool at their disposal (competition law), the same cannot be said about the U.S. Supreme Court. Since U.S. federal courts have jurisdiction over both copyright and antitrust, and since an antitrust counterclaim had been filed and already decided in Feist's favor when the case was argued before the Supreme Court, it was clear to the Court that an alternative antitrust route to resolve the conflict might be available..$^{83}$ Moreover, even though Feist's appeal concerned only the copyright question (because the court of appeals had not yet decided Feist's antitrust counterclaim) the petition for certiorari explicitly invited the Court to incorporate an antitrust-like analysis into its copyright ruling. Feist's petition contained the three following questions:

1. Can a telephone company copyright its directory of the phone numbers it has assigned to subscribers under its granted monopoly status, refuse to grant a license to those directory listings to a competing independent directory publisher, then use a copyright infringement action to enforce its refusal and prevent self-help access by the competitor to the telephone company's directory?

2. If such a refusal to deal is found to be an antitrust violation, would the copyright infringement action amount to "copyright misuse," thereby preventing enforcement of the copyright under a theory similar to that of "patent misuse"?

3. Does the copyright in a telephone directory by the telephone company prevent access to that directory as a source of names and numbers to compile a competing directory, or does copyright protection extend only to the selection, coordination, or arrangement of those names and numbers? ? $^{4}$

The first and second questions ostensibly invited the Court to consider the antitrust consequences of the conduct at issue. They invited the Court to uphold Rural's copyright in the listings but to create a relatively narrow exception that would permit Feist to compete. Indeed, regulatory intervention in such circumstances - a statutory monopoly in one market attempting to forestall competition in an adjacent market-is not uncommon. The Court thus faced three options. It could decline to hear the case, leave the scope of Rural's copyright intact, and let the parallel antitrust proceedings run their course; it could decide to hear the case and decide whether the doctrine of copyright misuse or an antitrust-like "exceptional circumstances" exception

\footnotetext{
${ }^{83}$ The Supreme Court opinion actually cited the district court's decision on the antitrust counterclaim. Feist, 499 U.S. at 343.

${ }^{84}$ Petition for Writ of Certiorari, Feist, 499 U.S. 340 (1991) (No. 89-1909), 1990 U.S. S. Ct. Briefs LEXIS 1110.
} 
would limit Rural's copyright; or it could, by addressing the petition's third question, tackle the copyrightability of the listings head-on.

Against this backdrop, the Court's decision to address only the third question can be seen as a deliberate decision to resolve the case as a matter of copyright first principles, rather than as a consequence of special circumstances, external to copyright law's core policies. Furthermore, when actually resolving the case, a unanimous Court adopted a solution so restrictive of IPRs that critics of the European approach should regard it as radical. The Court was clearly motivated by procompetitive considerations; it sought to prevent copyright from standing in the way of competition and innovation. In the Court's own words, its ruling would encourage "others to build freely upon the ideas and information conveyed by a work." ${ }^{85}$ To achieve this outcome, the Court not only denied Rural any copyright in its listings, but also raised the bar for copyrightability of compilations, declaring that the compiler's labor, i.e., its investment, is irrelevant to copyright laws, and holding that data is always free for others to take. Moreover, by basing its ruling on first principles of copyright law (grounded in the Constitution) ${ }^{86}$ rather than on the particular circumstances of the case (Rural's statutory monopoly status), the Court undermined attempts to use those circumstances to distinguish future cases. ${ }^{87}$

As one could easily predict, developments in the aftermath of Feist have tended to soften its potential impact on copyright protection for data compilations. For example, the Court's suggestion that facts cannot be protected because they do not originate from the author has led some courts to conclude that "created facts," such as various ratings, evaluations, or classifications, are not facts, but protected expressions. ${ }^{88}$ In addition, contracts that grant access to data compilations often contain terms that purport to control subsequent use of the data. Courts have continued to enforce these terms post-Feist. ${ }^{89}$ These developments notwithstanding, factual compilations continue to receive weaker protection in the United States than they do in Europe. As far as we can tell, mass-market contracts are generally as valid in Europe as they are in the United States, and even EU laws that regulate these contracts (e.g., the 1993 EU Directive on Unfair Terms of Consumer Contracts) ${ }^{90}$ focus on the in

\footnotetext{
${ }^{85}$ Feist, 499 U.S. at 350.

${ }^{86}$ See Justin Hughes, Created Facts and the Flawed Ontology of Copyright Law, 83 Notre Dame L. Rev. 43, 47-48 \& n.17 (2007) (noting that, while the Court chose to cast this decision in terms of a constitutional predicament, it could easily have reached the same conclusion through standard statutory interpretation).

${ }^{87}$ Feist, 499 U.S. at 361-63.

${ }^{88}$ Hughes, supra note 86 , at $46-57$.

${ }^{89}$ See, e.g., ProCD, Inc. v. Zeidenberg, 86 F.3d 1447 (7th Cir. 1996).

${ }^{90}$ Council Directive 93/13/EEC, On Unfair Terms in Consumer Contracts, 1993 O.J. (L 95) 29.
} 
personam aspects of the contractual relationships between sellers and consumers (assent, reasonableness, etc.) rather than on the public interest in preserving access to public domain information.

In addition, the European Union has consciously moved in a direction opposite to Feist through the 1996 enactment of Directive 96/9/EC on the legal protection of databases..$^{91}$ Article 3 of the Directive provides a Feist-like copyright in a database that, "by reason of the selection or arrangement of [its] contents, constitute[s] the author's own intellectual creation." ${ }^{92}$ Article 7, however, grants a sui generis right "to prevent extraction and/or re-utilization of the whole or of a substantial part . . . of the contents of [a] database" to a maker who "shows that there has been qualitatively and/or quantitatively a substantial investment in either the obtaining, verification or presenting of [those] contents." ${ }^{93}$ Article 7(1) thus adds a sui generis right atop the copyright, ${ }^{94}$ aimed at protecting the investment made in creating the database. Protecting that investment is exactly what Feist declined to do when it rejected a "sweat of the brow," or "industrious collection," basis for copyright. ${ }^{95}$

Moreover, unlike Feist, which, by casting its ruling in Constitutional terms created a serious stumbling block for many legislative initiatives to grant IP rights in databases, ${ }^{96}$ Magill did not have (and was never intended to have) a similar effect. While paragraph 47 of the Directive's preamble reaffirms the holding in Magill by clarifying that competition law may be applied to prevent anticompetitive abuses of the newly created right, Magill remains a tiny island of procompetitive interest in a wide and deep sea of IP protection. ${ }^{97}$

In conclusion, the courts in Magill and Feist faced a very similar problem: refusal to license factual listings, which prevented competition and innovation in an adjacent market. The European courts addressed this problem by up-

\footnotetext{
${ }^{91}$ Council Directive 96/9/EC, supra note 81; see infra note 97 (explaining that Feist was a catalyst for adoption of the EU Database Directive).

${ }_{92} I d$. art. 3(1).

${ }^{93}$ Id. art. $7(1)$.

${ }^{94}$ Daniel J. Gervais, The Protection of Databases, 82 Chi.-Kent L. Rev. 1109, 1121-22 (2007).

${ }^{95}$ Feist Publ'ns, Inc. v. Rural Tel. Serv. Co., 499 U.S. 340, 352-56 (1991).

${ }^{96}$ See, e.g., Assessment Techs. of WI, LLC v. WIREdata, Inc., 350 F.3d 640, 646 (7th Cir. 2003) ("Legal protection of databases as such (as distinct from programs for arranging the data ... ) cannot take the form of copyright, as the Supreme Court made clear in Feist when it held that the copyright clause of the Constitution does not authorize Congress to create copyright in mere data.").

${ }^{97}$ It is noteworthy that Feist was a catalyst for adopting the EU Database Directive. European lawmakers were persuaded that Feist would turn the United States into a database backwater, and that providing much broader IP protection for databases in the EU would help turn European publishers into industry leaders. See, e.g., Gervais, supra note 94, at 1119-20; Mark Powell, The European Union's Database Directive: An International Antidote to the Side Effects of Feist?, 20 FORDHAM INT'L L.J. 1215 (1997).
} 
holding the copyright, while citing "exceptional circumstances" to impose antitrust limitations on its exercise; in so doing, the European courts maintained the copyright owner's entitlement to be paid. The U.S. Supreme Court, by contrast, declined to adopt an antitrust solution, but instead denied copyright protection altogether. The Court thereby precluded any right to compensation and allowed anyone, regardless of the circumstances, to use the data. If one were to determine on the basis of these decisions which jurisdiction affords greater protection to IP rights, the European Union would plainly prevail.

\section{B. Copyright Misuse}

While the previous section discussed copyright protection for a particular type of subject matter, this and the following two sections discuss more general doctrines within American copyright law that promote innovative competition..$^{98}$ In this section we argue that the doctrine of copyright misuse in some sense substitutes for stricter antitrust scrutiny of the exercise of intellectual property rights. In other words, copyright misuse, which generally has no analogue within European copyright regimes, precludes certain anticompetitive uses of IPRs, which might in Europe require the application of antitrust doctrines.

The doctrine of copyright misuse has never been fully defined, and has not yet been endorsed (or rejected) by the Supreme Court. Under one formulation, the doctrine "prevents copyright holders from leveraging their limited monopoly to allow them control of areas outside the monopoly." 99 It has been applied in a variety of circumstances to render a copyright unenforceable where the copyright holder has acted in some way improperly. ${ }^{100}$

The seminal case on copyright misuse is Lasercomb America Inc. v. Reynolds. ${ }^{101}$ Lasercomb was a manufacturer of steel rule dies used to cut paper, and it developed a software program, Interact, that was used to create those dies. Lasercomb licensed four pre-release copies to Holiday Steel, a competing die manufacturer. The license agreement included a clause that expressly prohibited the licensee from "develop[ing] or assist[ing] in developing any kind of

\footnotetext{
${ }^{98}$ For an earlier analysis of copyright (and patent) misuse and how it reflects IP law's procompetitive interest, see Cotter, supra note 66, at 498-505.

${ }^{99}$ A\&M Records, Inc. v. Napster, Inc., 239 F.3d 1004, 1026 (9th Cir. 2001).

${ }^{100}$ For a more detailed discussion of the doctrine of copyright misuse than is possible here, see Brett Frischmann \& Dan Moylan, The Evolving Common Law Doctrine of Copyright Misuse: A Unified Theory and Its Application to Software, 15 Berkeley TECH. L.J. 865 (2000); Neal Hartzog, Gaining Momentum: A Review of Recent Developments Surrounding the Expansion of the Copyright Misuse Doctrine and Analysis of the Doctrine in Its Current Form, $10 \mathrm{MicH}$. Telecomm. \& Tech. L. Rev. 373 (2004); Kathryn Judge, Note, Rethinking Copyright Misuse, 57 Stan. L. Rev. 901 (2004).

101911 F.2d 970 (4th Cir. 1990).
} 
computer-assisted die-making software." 102 This prohibition, however, did not stop Holiday Steel from creating its own software, called PDS-1000, which largely copied Interact. Lasercomb brought a copyright infringement action against Holiday Steel and various former employees.

While the court found that infringement had occurred, it held that the doctrine of copyright misuse precluded Lasercomb from any relief from the defendants' infringement. ${ }^{103}$ The misuse in this case was Lasercomb's attempt to use its copyright in a particular expression, the Interact software code, "to suppress any attempt by the licensee to independently implement the idea which Interact expresses," 104 namely, "using CAD/CAM software to make steel rule dies." 105

Importantly, courts have repeatedly stated that a defendant need not demonstrate an antitrust violation by the plaintiff to establish the defense of copyright misuse. ${ }^{106}$ This means that defendants will be able to make use of the defense even where antitrust law would leave them without remedy. This disjunction between antitrust violations and copyright misuse can be seen in $\mathrm{Al}$ catel USA Inc. v. DGI Technologies, Inc. ${ }^{107}$ DSC was a manufacturer of telephone switching systems, for which it had developed a copyrighted operating system. While it sold its hardware, it only licensed the use of its operating system. Those licenses included terms that prohibited consumers from copying the software, disclosing it to third parties, or using DSC's software with hardware other than DSC-manufactured equipment. ${ }^{108}$ DGI, a rival hardware manufacturer, reverse-engineered DSC's products to develop its own products, which DGI contended were compatible with, but superior to, DSC's products. DSC brought suit, and DGI responded with a counterclaim for monopolization in violation of SEction 2 of the Sherman Act.

While both the district court and the circuit court dismissed DGI's antitrust counterclaim, the circuit court allowed DGI's defense of copyright misuse to DSC's infringement claim. The circuit court held that DSC misused its copyright by licensing its software only to be used in conjunction with DSC-manu-

\footnotetext{
${ }^{102} I d$. at 978.

${ }^{103} \mathrm{Id}$. at 979.

${ }^{104}$ Id. at 978.

${ }^{105} \mathrm{Id}$. at 978 n. 19.

${ }^{106} \mathrm{Id}$. at 978 ("[A] misuse need not be a violation of antitrust law in order to comprise an equitable defense to an infringement action. The question is not whether the copyright is being used in a manner violative of antitrust law (such as whether the licensing agreement is "reasonable"), but whether the copyright is being used in a manner violative of the public policy embodied in the grant of a copyright.").

107166 F.3d 772 (5th Cir. 1999).

${ }^{108} I d$. at 777.
} 
factured hardware. ${ }^{109}$ The circuit court held that, by conditioning its software licenses in this way, DSC had impermissibly attempted to expand its monopoly over the copyrighted software to the hardware itself. Thus, although it rejected DGI's counterclaim for monopolization, the court nonetheless held that DSC's attempt to use its copyright to affect competition in a secondary market precluded DSC from enforcing its copyright. ${ }^{110}$ Thus, Alcatel constitutes a case in which an American court, rather than using antitrust law to limit the scope of IPRs, instead used a doctrine internal to copyright law to restrain copyright overreach and promote innovative competition. ${ }^{111}$

By contrast, European copyright regimes generally do not have a doctrine equivalent to the American doctrine of copyright misuse. ${ }^{12}$ Regulating questionable uses of copyright of the type prohibited by the doctrine of copyright misuse in the United States is thus left in European jurisdictions to the higher and stricter standards of competition law.

\section{The Merger Doctrine}

Another doctrine that American courts have applied to limit anticompetitive uses of copyright is the merger doctrine. ${ }^{113}$ The merger doctrine is closely related to the idea-expression dichotomy. Under the idea-expression dichotomy, copyright will only be granted over the particular expression of an idea, not over the idea itself. ${ }^{114}$ The merger doctrine represents in some sense a further manifestation of the idea-expression dichotomy; under that merger doctrine, "even expression is not protected in those instances where there is only one or so few ways of expressing an idea that protection of the expres-

${ }^{109} I d$. at $792-95$.

${ }^{110}$ For a critique of the Fifth Circuit's decision on the basis that it extended the doctrine of copyright misuse too far into the realm of procompetitive considerations, see Theodore Dorenkamp, Copyright Misuse or a Right to Compete?: A Critique of Alcatel USA v. DGI Technologies, 9 TeX. InTell. Prop. L.J. 269 (2001).

111 It is noteworthy that in Assessment Technologies of WI, LLC v. WIREdata, Inc., 350 F.3d 640 (7th Cir. 2003), the Seventh Circuit endorsed the view that copyright misuse is not limited to acts violating the antitrust laws and explicitly reversed its earlier skeptical position toward the doctrine, namely that antitrust is the proper tool to deal with anticompetitive uses of copyright. Id. at 647.

${ }^{112}$ See generally Haris Apostolopoulos, The Copyright Misuse Doctrine on Computer Software: A Redundant Doctrine of U.S. Copyright Law or a Necessary Addition to E.U. Copyright Law?, 24 J. Marshall J. Computer \& INFo. L. 571 (2006) (arguing that a more flexible doctrine would be less appropriate in the context of European Union law than it is in American law); Coco, supra note 3, at 7-8.

${ }^{113}$ For an earlier analysis of the merger doctrine and how it reflects copyright law's procompetitive interest see Cotter, supra note 66, at 506-09.

${ }^{114}$ This longstanding principle in the common law has also been codified in the current U.S. Copyright Act. Section 102(b) of the Copyright Act specifies that "[i]n no case does copyright protection for an original work of authorship extend to any idea, procedure, process, system, method of operation, concept, principle, or discovery, regardless of the form in which it is described, explained, illustrated, or embodied in such work.” 17 U.S.C. § 102(b). 
sion would effectively accord protection to the idea itself." 115 Thus, the merger doctrine denies an author exclusivity over his or her expression where such protection would inevitably give the author exclusivity over the idea itself.

We are not suggesting that the idea-expression dichotomy is unique to American copyright law or that European copyright regimes contain no analogous principle. Virtually all copyright regimes distinguish protectable expression from unprotectable ideas; even multilateral treaties such as the Agreement on Trade-Related Aspects of Intellectual Property Rights (TRIPS) draw a distinction between ideas and their expression. ${ }^{116}$ Therefore, to the extent that the merger doctrine flows directly from the idea-expression dichotomy, most copyright regimes should recognize the doctrine in some form. ${ }^{117}$ To date, however, few jurisdictions have explicitly embraced the doctrine. What makes American copyright law unique is not only the robust nature of its merger doctrine, but also the frequency with which that doctrine has been applied with express reference to antitrust considerations.

The litigation between the New York Mercantile Exchange (NYMEX) and the Intercontinental Exchange (ICE) provides a good example of such an application. NYMEX and ICE were rival commodity exchanges. At the end of each business day, NYMEX determined the settlement prices for its futures contracts. NYMEX disseminated those settlements prices to the public, as it was required to under applicable securities legislation. ICE began using NYMEX's settlement prices in its own clearing operations, and NYMEX subsequently brought a copyright infringement action against ICE. ICE counterclaimed, alleging that NYMEX's unwillingness to license its prices to ICE constituted an impermissible refusal to deal under Section 2 of the Sherman Act.

The Southern District of New York dismissed ICE's antitrust counterclaim. ${ }^{118}$ The court accepted the existence and validity of the essential facilities doctrine, but held that the Supreme Court's decision in Trinko barred ICE's essential facilities claim. In Trinko, the district court observed, the Court had held that the essential facilities doctrine is inapplicable where a

\footnotetext{
115 Kregos v. Associated Press, 937 F.2d 700, 705 (2d Cir. 1991).

116 See Agreement on Trade-Related Aspects of Intellectual Property Rights, art. 9(2), Apr. 15, 1994, Marrakesh Agreement Establishing the World Trade Organization, Annex 1C, 108 Stat. 4809, 1869 U.N.T.S. 299 ("Copyright protection shall extend to expressions and not to ideas, procedures, methods of operation or mathematical concepts as such.”).

${ }^{117}$ At least one Canadian court of appeal has adopted the merger doctrine. See Delrina Corp. v. Triolet Sys. Inc. (2002), 58 O.R. 3d 339, III 48-52 (Can. Ont. C.A.) (noting that despite the reluctance to apply the doctrine in the United Kingdom, the merger doctrine applies in Canada as it applies in the United States because it flows directly from the idea-expression dichotomy).

${ }^{118}$ N.Y. Mercantile Exch., Inc. v. IntercontinentalExch., Inc., 323 F. Supp. 2d 559, 567-72 (S.D.N.Y. 2004).
} 
regulatory body has the authority to compel access. Because the Commodity Futures Trading Commission had the statutory power to order NYMEX to disclose its prices, the court declined to apply the essential facilities doctrine. The court proceeded to hold that the Aspen Skiing doctrine did not apply on the facts of the case, and thus dismissed ICE's counterclaim.

Notwithstanding the dismissal of its antitrust counterclaim, ICE was able to continue using the settlement prices because it successfully argued that NYMEX had no copyright in the settlement prices. Both the district court and the Second Circuit held that the settlement prices created by NYMEX were so closely linked to and reflective of the conduct of market participants that to give copyright protection to those settlement prices would improperly protect the "idea" of the taking prices in the market. ${ }^{119}$

The Second Circuit's rationale for applying the merger doctrine was laden with competition concerns: "To grant NYMEX copyright protection here 'would effectively accord protection to the idea itself' . . . and bar ICE or other competitors from valuing NYMEX's contracts." 120 The court's rationale suggests that it was concerned with the anticompetitive outcome that would result from giving NYMEX an enforceable copyright in the settlement prices. Additionally, the court observed that "policy considerations weigh heavily in determining the appropriate application of the merger doctrine."121 The court acknowledged that an overly aggressive application of the merger doctrine would significantly reduce the scope of copyright protection and thereby diminish incentives to innovate; the court concluded, however, that these concerns did not arise in the case before it. Because NYMEX needed to disseminate settlement prices, both to operate its commodity exchange and to comply with its regulatory obligations, the ruling would not reduce its incentive to do so. ${ }^{122}$ This case thus presents another situation where the perceived need for balance between the incentives to innovate and competitive markets was satisfied entirely within the domain of copyright law.

\footnotetext{
119 N.Y. Mercantile Exch., Inc. v. IntercontinentalExch., Inc., 497 F.3d 109, 116-18 (2d Cir. 2007). For critical commentary on this decision, see Jeremy V. Murray, Note, The Death of Copyright Protection in Individual Price Valuations, a Flawed Merger Doctrine, and Financial Market Manipulation: New York Mercantile Exchange v. IntercontinentalExchange, 57 Buff. L. Rev. 279 (2009).

${ }^{120}$ N.Y. Mercantile Exchange, 497 F.3d at 118.

${ }^{121} I d$. For a discussion of the importance of policy considerations in the application of the merger doctrine to compilations, see CCC Information Services, Inc. v. Maclean Hunter Market Reports, Inc., 44 F.3d 61, 72 (2d Cir. 1994) ("In cases of wholesale takings of compilations, a selective application of the merger doctrine, withholding its application as to soft ideas infused with taste and opinion, will carry out the statutory policy to protect innovative compilations without impairing the policy that requires public access to ideas of a more important and useful kind.").

${ }^{122}$ N.Y. Mercantile Exchange, 497 F. 3d at 118.
} 
The NYMEX case is an interesting example of the methodological divergence of American and European courts' approaches to such cases. In an article published shortly after the district court's rejection of ICE's antitrust counterclaim (but before its decision on the copyright claims), Eleanor Fox argued that if ICE's antitrust counterclaim had been addressed by a European court applying IMS Health, the court would have likely found that NYMEX's conduct constituted an impermissible refusal to deal. ${ }^{123}$ From this analysis, Fox concluded that European antitrust authorities are more activist and more willing to impose positive obligations on parties than are American antitrust authorities. ${ }^{124}$ On this point, she was undoubtedly correct. As the subsequent developments of this case suggest, however, the difference in how antitrust law applies to such a case does not necessarily reflect divergence, from a competition perspective, in the substantive outcomes of the cases. While European authorities might have found an impermissible refusal to deal, the Second Circuit applied the merger doctrine to limit NYMEX's copyright in the information, thereby allowing ICE to use that information to compete with NYMEX.

Unlike Feist, which ruled that the listings were not copyrightable as a matter of copyright first principles, and that copying them was legal per se, NYMEX applied a rule of reason analysis. The Second Circuit ruled that the settlement prices in NYMEX constituted a merger of ideas and expression in light of the particular circumstances of the market. Moreover, the court did so only after it concluded, also based on market characteristics, that applying the merger doctrine would not seriously undermine the incentive to create the work in the first place. ${ }^{125}$ The analysis-undertaken within copyright law-is not dissimilar to the analyses undertaken in the EU cases applying competition law.

American courts have also applied the merger doctrine with competition concerns in mind in the context of computer software. In Lexmark International v. Static Control Components, Inc., the Sixth Circuit held that the merger doctrine precluded copyright protection for technological lock-out codes that prevented the use of unauthorized components. ${ }^{126}$ In so holding, the

\footnotetext{
${ }^{123}$ Fox, supra note 3, at 961-64.

${ }^{124} I d$. at $964-66$.

${ }^{125}$ N.Y. Mercantile Exchange, 497 F.3d at 116-18.

126 The court explained:

Generally speaking, "lock-out" codes fall on the functional-idea rather than the original-expression side of the copyright line. Manufacturers of interoperable devices such as computers and software, game consoles and video games, printers and toner cartridges, or automobiles and replacement parts may employ a security system to bar the use of unauthorized components. To "unlock" and permit operation of the primary device (i.e., the computer, the game console, the printer, the car), the component must contain either a certain code sequence or be able to respond appropriately to an authen-
} 
Sixth Circuit applied the merger doctrine to preclude copyright protection where such protection would extend the scope of exclusivity beyond the copyrighted work itself.

Another significant application of the merger doctrine was Computer Associates International, Inc. v. Altai, Inc., in which the Second Circuit held that copyright does not protect elements of computer software that are dictated by efficiency considerations or by external factors, such as the mechanical specifications of the computer on which the software will run. ${ }^{127}$ In reaching this conclusion, the court paid particular heed to the significant role that technical requirements and industry-wide standards often play in dictating the particular form that a computer program takes. Thus, the Second Circuit was careful to avoid giving exclusive control over an entire genre of software to any particular software manufacturer simply because it was the first to implement a particular standard.

The merger doctrine might have provided a potential basis for resolving the IMS Health case, had it been decided under American law. As noted above, ${ }^{128}$ IMS Health sought to enforce a copyright over its 1860 brick structure for categorizing pharmaceutical sales information on a geographic basis. Because IMS Health had devised the structure in collaboration with the pharmaceutical industry, its structure quickly became an industry standard, and pharmaceutical companies refused to purchase marketing data that was not formatted according to this structure. An American court considering this case might have reasoned that granting copyright protection to the brick structure would effectively grant IMS Health a monopoly not only over its brick structure, but also over the entire market for pharmaceutical sales information. An American court might also have regarded the IMS Health structure as a non-copyrightable "system." 129 Additionally, the policy considerations to which the Second Circuit referred in the NYMEX case would not weigh against applying the merger doctrine in the IMS Health case. Because the product that IMS Health sold was pharmaceutical data, not the its brick structure, and because some type of structure was necessary to categorize these data, there would be little risk that denying copyright protection would reduce incentives to innovate.

\footnotetext{
tication process. To the extent compatibility requires that a particular code sequence be included in the component device to permit its use, the merger and scènes à faire doctrines generally preclude the code sequence from obtaining copyright protection. Lexmark Int'l v. Static Control Components, Inc., 387 F.3d 522, 536 (6th Cir. 2004).

${ }^{127}$ Computer Assocs. Int'l, Inc. v. Altai, Inc., 982 F.2d 693 (2d Cir. 1992).

${ }^{128}$ See supra text accompanying notes 39-45.

${ }^{129}$ See Baker v. Selden, 101 U.S. 99, 104 (1879) (holding that, while a book describing an improved system for book-keeping may be copyrighted, "as a book intended to convey instruction in the art, any person may practise and use the art . . . described and illustrated therein," and "[t]he copyright of a book on book-keeping cannot secure the exclusive right to make, sell, and use account-books prepared upon the plan set forth in such a book").
} 
While this reasoning is by no means conclusive, it does illustrate how an American court might have resolved the IMS Health case and achieved the same procompetitive outcomes through doctrines internal to copyright law rather than through antitrust law.

\section{FAIR USE}

Fair use is another (and perhaps the ultimate) doctrine of American copyright law serving a procompetitive interest. ${ }^{130}$ The fair use doctrine permits, under some conditions, the copying of copyrighted material for legitimate purposes. ${ }^{131}$ Most important for the purpose of this article, fair use has been invoked on certain occasions to allow copying for the purpose of competing with the owner of the copyrighted work. For example, in Atari Games Corp. v. Nintendo of America Inc., the Federal Circuit held that "reverse engineering object code to discern the unprotectable ideas in a computer program is a fair use." ${ }^{132}$ Similarly, in Sega Enterprises Ltd. v. Accolade Inc., the Ninth Circuit held that of the fair use doctrine permitted Accolade to copy header code that Sega had inserted into its video game system and games to prevent competing manufacturers' games from functioning on Sega's console. ${ }^{133}$ Thus, in these cases, courts have applied the fair use doctrine to allow competitors to develop products that compete with the copyright holder's products.

Admittedly, similar doctrines relating to reverse engineering exist within European copyright regimes. In particular, the Computer Programs Directives

\footnotetext{
${ }^{130}$ For an earlier analysis of fair use and how it reflects copyright law's procompetitive interest, see Cotter, supra note 66, at 509-15.

13117 U.S.C. $\S 107$ (“ [T] he fair use of a copyrighted work . . f for purposes such as criticism, comment, news reporting, teaching . . . scholarship, or research, is not an infringement of copyright. In determining whether the use made of a work in any particular case is a fair use the factors to be considered shall include-(1) the purpose and character of the use, including whether such use is of a commercial nature or is for nonprofit educational purposes; (2) the nature of the copyrighted work; (3) the amount and substantiality of the portion used in relation to the copyrighted work as a whole; and (4) the effect of the use upon the potential market for or value of the copyrighted work.").

132 Atari Games Corp. v. Nintendo of Am. Inc., 975 F.2d 832, 843 (Fed. Cir. 1992).

133 The Ninth Circuit explained:

Accolade contends, finally, that its disassembly of copyrighted object code as a necessary step in its examination of the unprotected ideas and functional concepts embodied in the code is a fair use that is privileged by section 107 of the [Copyright] Act. Because, in the case before us, disassembly is the only means of gaining access to those unprotected aspects of the program, and because Accolade has a legitimate interest in gaining such access (in order to determine how to make its cartridges compatible with the Genesis console), we agree with Accolade. Where there is good reason for studying or examining the unprotected aspects of a copyrighted computer program, disassembly for purposes of such study or examination constitutes a fair use.
}

Sega Enters. Ltd. v. Accolade, Inc., 977 F.2d 1510, 1520 (9th Cir. 1993). 
incorporate, ${ }^{134}$ and several European jurisdictions have codified, ${ }^{135}$ a rule that permits parties to copy software as a part of the process of reverse engineering that software. Even in other contexts and in the absence of explicit legislation, European courts may invoke non-copyright principles to read limitations into copyright law that have an effect similar to fair use. ${ }^{136}$ Therefore, to the extent that European copyright regimes contain rules equivalent to those developed under the American fair use doctrine, American copyright law demonstrates no stronger procompetitive interest in this respect than do European copyright regimes.

One crucial aspect of the American doctrine of fair use, however, makes it more capable than European copyright regimes of fostering procompetitive outcomes: American fair use relies on an open-ended system in which courts determine in each particular case whether the use of copyrighted materials was fair. Most European systems, on the other hand, provide a statutory list of specific uses of copyrighted materials that do not constitute infringement. ${ }^{137}$ Moreover, European courts tend to interpret these statutory exceptions narrowly and restrictively. ${ }^{138}$ Thus, European copyright regimes are in this respect necessarily reactive, while American fair use doctrine can bend to the facts of particular cases to foster ad hoc procompetitive outcomes. These outcomes not only resolve particular disputes, but also create a body of case law that informs future innovators even if Congress takes no action.

A comparison of the factors set out in Magill and the factors that U.S. law considers in fair use analysis reveals both considerable similarities and marked differences. Magill's "new product" requirement is similar to what U.S. copyright law considers "transformative use." The transformative use inquiry asks "whether the new work merely 'supersede[s] the objects' of the original creation ... or instead adds something new, with a further purpose or different character, altering the first with new expression, meaning, or mes-

\footnotetext{
${ }^{134}$ Council Directive 91/250/EEC, supra note 82, arts. 5(3), 6, replaced by Council Directive 2009/24/EC, supra note 82, arts. 5(3), 6.

${ }^{135}$ See, e.g., Code CIVIL [C. CIV.] art. L. 122-6-1-IV (Fr.).

${ }^{136}$ For example, despite Germany's lack of an American-style fair use doctrine, German courts have recently reached outcomes very similar to those that American courts would likely reach in similar circumstances. In one case, the German Federal Constitutional Court allowed Heiner Müller, a German playwright, to quote excerpts of Bertolt Brecht's works. The court based its ruling on a copyright limitation that it inferred from the German constitution's protection for freedom of expression. See Bundesverfassungsgericht [BVerfG] [Federal Constitutional Court] June 29, 2000, 2001 Gewerblicher Rechtsschutz und Urheberrecht [GRUR] 149 (F.R.G.).

137 See generally J.A.L. Sterling, World Copyright Law 537-40 (3d ed. 2008).

138 See Case C-5/08, Infopaq Int'l A/S v. Danske Dagblades Forening, 2009 E.C.R. I-6569, IIII 40-41, 56-57 (Judgment of the Court) (holding that the main objective of Council Directive 2001/29/EC, supra note 82, is to introduce a high level of protection of intellectual property, that the acts covered by the right of reproduction should therefore be construed broadly, and that exceptions to this right should be interpreted strictly).
} 
sage." ${ }^{139}$ As the U.S. Supreme Court held in Campbell v. Acuff-Rose Music, the more transformative the use, the more likely it will be deemed fair. ${ }^{140}$ According to recent studies, the transformative use doctrine plays an increasingly important role in current U.S. copyright fair use jurisprudence, a trend that can be traced to the Supreme Court's 1994 decision in Campbell, ${ }^{141}$ handed down only one year before Magill.

Another similarity is that, while the Magill formulation does not discriminate among different types of works, its application has nonetheless been limited to works that, even if protected, are at the margin, rather than the core, of copyright protection. In the United States, whether a work is at the core or the margin of copyright protection affects the likelihood that the use in question will be deemed "fair." 142 Courts allow "greater leeway . . . to a claim of fair use where the work is factual or informational," 143 as opposed to a work that is creative or expressive. ${ }^{144}$

U.S. courts applying the factors for analysis of fair use set forth in Section 107 of the Copyright Act sometimes consider what non-infringing alternatives might be available to the defendant. ${ }^{145}$ This consideration is similar to the "indispensability" requirement in Magill. ${ }^{146}$ Lastly, "the effect on the market" test in fair use requires courts to consider "the effect of the use upon the

\footnotetext{
${ }^{139}$ Campbell v. Acuff-Rose Music, Inc., 510 U.S. 569, 579 (1994).

${ }^{140} I d$.
}

${ }^{141}$ Neil Weinstock Netanel, Making Sense of Fair Use, 15 Lewis \& Clark L. Rev. 715, 771 (2011) (noting that "the embrace of the transformative use doctrine represents a sea change in fair use case law that has finally come to fruition in the period since 2005, even if we can trace its beginnings to the Supreme Court's 1994 decision in Campbell'); Matthew Sag, Predicting Fair Use, 73 Оніо Sт. L.J. 47, 55, 79-80 (2012).

14217 U.S.C. $\S 107$.

${ }^{143}$ Blanch v. Koons, 467 F.3d 244, 256 (2d Cir. 2006) (citing 2 Howard B. Abrams, The LAW OF COPYRIGHT, $\S 15: 52$ (2006)).

${ }^{144} I d$.

${ }^{145}$ See, e.g., Sega Enters. Ltd v. Accolade, Inc., 977 F.2d 1510, 1527-28 (9th Cir. 1993) (finding that "where disassembly is the only way to gain access to the ideas and functional elements embodied in a copyrighted computer program and where there is a legitimate reason for seeking such access, disassembly is a fair use of the copyrighted work, as a matter of law"); see also Assessment Techs. of WI, LLC v. WIREdata, Inc., 350 F.3d 640, 645 (7th Cir. 2003) ("[I]f the only way WIREdata could obtain public-domain data about properties in southeastern Wisconsin would be by copying the data in the municipalities' databases as embedded in Market Drive, so that it would be copying the compilation and not just the compiled data only because the data and the format in which they were organized could not be disentangled, it would be privileged to make such a copy ....").

146 Joined Cases C-241/91 P \& C-242/91 P, Radio Telefis Eireann (RTE) \& Indep. Television Publ'ns Ltd (ITP) v. Comm'n (Magill), 1995 E.C.R. I-743, II 53 (observing that the television stations "were, by force of circumstance, the only sources of the basic information on programme scheduling which is the indispensable raw material for compiling a weekly television guide"). 
potential market for or value of the copyrighted work." 147 This factor resembles the "new product" requirement from Magill; it is also consistent with the finding in Microsoft that compulsory disclosure of interoperability information would not allow Microsoft's competitors to clone its products and would not reduce Microsoft's incentives to innovate. ${ }^{148}$

Despite the similarities, there are two significant differences. First, as a remedy for abuse of dominance, IP holders may be compelled to license their IPRs in Europe only if it has been established that the IP holder holds a dominant position in the market and that it has abused that position. In contrast, fair use is potentially available with respect to all works, and the analysis focuses on the defendant's conduct, not on the copyright owner's conduct and market power. ${ }^{149}$ Second, in Europe, the copyright owner is still entitled to charge a reasonable fee for the use of the work, whereas under fair use, the fee is zero. While the similarities reflect the ability of the two regimes to reach the same competitive result in a given case, the differences support our view of the relative weakness of copyright protection in the United States as compared to Europe.

\section{ANTITRUST-BASED VS. COPYRIGHT-BASED MECHANISMS FOR FOSTERING COMPETITIVE MARKETS: TWO SIDES OF A BIASED COIN?}

The foregoing sections have argued that the divergence between European and American treatment of anticompetitive uses of intellectual products may not be so broad as commonly supposed. On certain questions, both jurisdictions achieve substantively similar outcomes, albeit through different means.

In this Part we take the analysis one step further and posit that there are ways in which the American model of copyright-based regulation of anticompetitive uses of intellectual property actually provides less, rather than more, protection to intellectual property rights than does the European model of antitrust-based regulation. There are three respects in which this is true:

14717 U.S.C. § 107(4). In assessing the likelihood of harm, courts may infer market harm "when a commercial use amounts to mere duplication of the entirety of an original." Campbell v. Acuff-Rose Music, Inc., 510 U.S. 569, 591 (1994). In such cases, the use "clearly "supersede[s] the objects' . . . of the original and serves as a market replacement for it, making it likely that cognizable market harm to the original will occur. But when, on the contrary, the second use is transformative, market substitution is at least less certain, and market harm may not be so readily inferred." Id. (citations omitted).

${ }^{148}$ Case T-201/04, Microsoft Corp. v. Comm'n, 2007 E.C.R. II-3601, IITI 700-701.

${ }^{149}$ Somewhat paradoxically, the effect on the market test in U.S. fair use analysis could benefit a copyright owner with a dominant position; it is more likely that a use would harm the sale of a work that enjoys a dominant position than it would harm the sale of a work for which plenty of substitutes are already available. 
First, antitrust-based regulation of copyrighted works is more context-specific than those forms of copyright-based regulation that ultimately deny the owner a valid copyright. Although antitrust may compel copyright owners to license their work, copyright continues to protect the work, and owners can enforce that copyright against others in settings that do not give rise to an abuse of dominant position. ${ }^{150}$ Moreover, the copyright remains intact unless and until the charge of abuse is established. By contrast, a finding that a work is not entitled to copyright protection-because the merger doctrine applies or because the work is an uncopyrightable compilation of facts-or that the work may be copied under fair use, narrows the producer's ability to appropriate supracompetitive returns through licensing or sale of copies, through a strategic refusal to license, or through threats of litigation. ${ }^{151}$

Second, it may simply be easier for parties to convince courts that competition concerns warrant the application of procompetitive copyright doctrines, such as the merger doctrine, copyright misuse, or fair use, than it would be for them to seek relief under antitrust laws. Although antitrust law and copyright law might assign the burden of proof to the same party, ${ }^{152}$ elements of antitrust law that play a major role in limiting its reach are often absent-and thus need not be proven - when copyright law's internal limiting doctrines are invoked. For example, both monopolization claims under Section 2 of the Sherman Act and abuse of dominance claims under Article 102 TFEU ordinarily require the plaintiff to define a relevant market and prove that the defendant had a high degree of market power. These requirements bar many antitrust cases, but they are absent—at the very least explicitly—from the regulation of anticompetitive outcomes from within copyright law. ${ }^{153}$ Similarly, where a particular practice is not per se illegal, a plaintiff in an antitrust suit will have to prove

\footnotetext{
${ }^{150}$ The U.S. misuse doctrine, by contrast, typically bars the enforcement of the IPR until the misuse has been purged, even if the defendant pleading misuse is unaffected by it. See Apostolopoulos, supra note 112, at 585 n.91.

${ }^{151}$ Additionally, where the compulsory licensing of copyright works under antitrust law entails licensing the work to competitors at a reasonable rate, antitrust-based regulation still contemplates a flow of royalties between the user and the owner, while the copyright-based modes of regulation that eviscerate the copyright do not.

${ }^{152}$ Copyright misuse and fair use are both affirmative defenses, meaning that the burden of proof is on the defendant. The legal nature of the merger doctrine is less clear, and courts have split on whether it affects the copyrightability of a work or merely serves as a defense in an infringement action. See Mason v. Montgomery Data, Inc., 967 F.2d 135, 138 n.5 (5th Cir. 1992).

${ }^{153}$ In the United States, this burden to show market power has become substantially higher since Illinois Tool Works, in which the Supreme Court decided that a patent does not by itself confer market power upon the patentee. Ill. Tool Works Inc. v. Indep. Ink, Inc., 547 U.S. 28, 45-46 (2006). Although this decision occurred in the patent context, it can reasonably be inferred that the decision destroys any legal presumption in American law that market power arises from the mere possession of an IPR. But see Katz, supra note 2 (arguing that courts may still reasonably infer the existence of market power from the existence of IPRs).
} 
that the defendant's conduct resulted or will likely result in anticompetitive outcomes in the market. This requirement is also absent from (or at least less rigorous in) internal regulation of anticompetitive uses of copyrights. ${ }^{154}$ Thus, even when the substantive outcome is similar, the American means to achieve it are more widely available and easier to use.

Third, the context-specific nature of an abuse-of-dominance finding renders it difficult to extend such a finding to analogous cases. In contrast, when a court resolves competition concerns by tweaking the underlying copyright, that resolution can easily spill over to similar cases that involve other copyright holders in other industries, thus weakening the rights of copyright holders more broadly. For example, parties can reasonably rely on the holding in Feist and copy alphabetically ordered compilations of data in a wide array of contexts because the outcome in Feist is based on a legal principle of general applicability. Unless market conditions are highly similar, however, copiers of data are less likely to assume that the holding in Magill would shield them from copyright infringement liability, because Magill was specifically limited to its exceptional circumstances. Similarly, even though a finding of fair use is highly context specific, the principles articulated in every such case are applicable to a wide swath of other circumstances; their application usually does not depend on the copyright owner's possession of significant market power in a given industry, or on clearly articulated anticompetitive outcomes. In other words, an antitrust resolution of refusal to deal cases tends to have an inter partes effect, while an IP resolution tends to have an in rem effect.

\section{COMPARING THE PROCESSES OF ANTITRUST ENFORCEMENT}

To this point, we have questioned the conventional wisdom on the relative strength of copyright protection in the United States and the European Union primarily by focusing on substantive differences in copyright law regimes on either side of the Atlantic. In this Part, we introduce an additional consideration: the process of antitrust enforcement. Specifically, we posit that the processes by which antitrust law is enforced in the United States may provide another reason for thinking that IPRs are, in effect, less secure in the United States than in Europe.

The starting point for this discussion is the significantly greater prevalence of private antitrust suits in the United States than in Europe. ${ }^{155}$ Between 1990

\footnotetext{
154 See Mark A. Lemley \& Mark P. McKenna, Is Pepsi Really a Substitute for Coke? Market Definition in Antitrust and IP, 100 GEo. L.J. 2055 (2012) (explaining that, in fair use, merger, or misuse cases, the court might engage in some sort of market analysis, but not as rigorous an analysis as the analyses undertaken in antitrust cases).

155 See generally D. Daniel Sokol, Antitrust, Institutions, and Merger Control, 17 Geo. Mason L. Rev. 1055, 1081-85 (2010).
} 
and 2005, plaintiffs in the United States filed an average of fewer than 750 federal antitrust cases per year. From 2006 to 2008, the number was higher, with over 1,000 federal antitrust cases filed per year. ${ }^{156}$ In recent years the numbers have declined, possibly as a result of heightened pleading standards applied in the aftermath of Twombly ${ }^{157}$ The number of federal antitrust cases filed reached a low of 452 cases in the period between October 2010 and September 2011. ${ }^{158}$ Even with this decline, however, the private enforcement of European antitrust law remains exceptionally limited by comparison. A 2004 Report by the law firm Ashurst, commissioned by the Directorate General for Competition, found only 60 decided claims for damages in total from the (then) twenty-five member states of the European Union, either under national law, EU law, or both. ${ }^{159}$ These figures, even if not perfectly comparable, demonstrate that private antitrust suits are vastly more commonplace in the United States than in Europe. The reasons for the relatively limited use of private antitrust actions in Europe are myriad, and they have been discussed elsewhere at great length. ${ }^{160}$ Several key reasons for this divergence are important here.

One factor is the magnitude of damages available in the United States. Under Section 4 of the Clayton Act, successful plaintiffs in antitrust suits can recover treble damages as well as reasonable attorney's fees, in contrast to normal practice in American litigation. ${ }^{161}$ By contrast, supracompensatory damages are generally unavailable in most European states. ${ }^{162}$ Indeed, while U.S. courts have long entertained private treble-damages actions, European courts have only relatively recently concluded that damages are available at all for breaches of EU competition law. ${ }^{163}$ Thus, the financial reward for suc-

156 Thomas J. Dillickrath, C. Scott Hataway \& J. Maren Schmidt, Private Enforcement, in THE Antitrust Review of the Americas 2010, at 40 (2009).

${ }^{157}$ Bell Atl. Corp. v. Twombly, 550 U.S. 544 (2007); see also Donald W. Hawthorne, Recent Trends in Federal Antitrust Class Action Cases, Antitrust, Summer 2010, at 58.

158 Administrative Office of the United States Courts, Judicial Business of the United States Courts: 2011 Annual Report of the Director 126 (2012), available at http://www.uscourts.gov/uscourts/Statistics/JudicialBusiness/2011/JudicialBusiness2011.pdf.

159 Denis Waelbroeck, Donald Slater \& Gil Even-Shoshan, Study on the Conditions of Claims for Damages in CASE of Infringement of EC Competition Rules: Comparative REPORT 1 (2004) [hereinafter AshuRst REPORT], available at http://ec.europa.eu/competition/ antitrust/actionsdamages/comparative_report_clean_en.pdf.

${ }^{160}$ See, e.g., id. at 102-31.

16115 U.S.C. $\S 15$.

162 See Ashurst Report, supra note 159, at 129-30.

163 Only in 2001, the European Court of Justice held that national courts must provide a remedy in damages for the enforcement of the rights and obligations created by EU competition law. See Case C-453/99, Courage Ltd v. Bernard Crehan, 2001 E.C.R. I-6297 (Judgment of the Court). It took another three years for courts in the United Kingdom to award damages in that case, the first reported award of damages in the United Kingdom. See Donncadh Woods et al., Private Enforcement of Community Competition Law: Modernisation and the Road Ahead, CoMPetition Pol'y NewsL., Summer 2004 (No. 2), at 31, 32. 
cessful antitrust plaintiffs is much greater in the United States than it is in Europe.

Important procedural differences also explain why private actions are less frequent in Europe. A key difference is the widespread availability of class actions in the United States. By their nature, class actions make possible certain types of litigation that could not be feasibly brought by individual plaintiffs. The significance of the availability of class actions for American antitrust litigation is great; of the 1,239 federal antitrust cases filed in 2008, 765 were class actions. ${ }^{164}$ In 2009 , following Twombly, the number of antitrust class actions filed dropped to $375,{ }^{165}$ but this is still significantly more than the number of class actions filed in the European Union, because most European states do not have a procedure directly analogous to the class action. ${ }^{166}$ While many European states are now introducing or exploring the possibility of introducing some type of collective action, they seldom go as far as the American model of opt-out class actions. For example, while the European Commission discussed the desirability of some form of collective redress for antitrust violations in its 2008 White Paper on Damages Actions, it proposed only the use of representative actions and opt-in collective actions rather than American-style opt-out class actions. ${ }^{167}$

The broader scope for discovery available in American litigation may also facilitate the assertion of antitrust claims. Under the Federal Rules of Civil Procedure, parties have a right to discovery of any relevant, non-privileged document. ${ }^{168}$ By contrast, most European states do not impose nearly so expansive an obligation on parties to litigation to disclose this type of information to other parties. ${ }^{169}$ While the 2008 EC White Paper also recognized the need for increased disclosure in private antitrust cases, the model of disclosure it advocated fell well short of the expansive model of discovery found in the United States. ${ }^{170}$

\footnotetext{
${ }^{164}$ Dillickrath et al., supra note 156 , at 40 .

165 Hawthorne, supra note 157 , at 58.

166 Ashurst RePORT, supra note 159, at 45.

${ }^{167}$ Comm'n of the Eur. Cmtys., Commission White Paper on Damages Actions for Breach of the EC Antitrust Rules, at 4, COM (2008) 165 final (Apr. 2, 2008) [hereinafter White Paper], available at http://ec.europa.eu/competition/antitrust/actionsdamages/_white_paper/_en.pdf.

${ }^{168}$ FeD. R. Civ. P. 26.

169 See Ashurst RePORT, supra note 159, at 61-64.

${ }_{170}$ See White Paper, supra note 167. Under the model put forward by the Commission in its White Paper, disclosure of documents would be by court order rather than party-initiated as in the United States, and disclosure would only be ordered where the claimant has:

- presented all the facts and means of evidence that are reasonably available to him, provided that these show plausible grounds to suspect that he suffered harm as a result of an infringement of competition rules by the defendant;

- shown to the satisfaction of the court that he is unable, applying all efforts that can reasonably be expected, otherwise to produce the requested evidence;
} 
These procedural factors help explain the much larger role that private antitrust litigation plays in the United States as compared to Europe. This role, in turn, helps explain why private litigation provides a check on the exercise of IPRs in the United States that it does not provide, at least to nearly the same degree, in Europe. Thus, even if the substance of American antitrust law provides less of a check on the exercise of IPRs than does EU competition law, the higher likelihood that an IP holder will be subjected to an antitrust claim in the United States may result in a greater practical check on the exercise of IPRs. As cases such as Feist and NYMEX illustrate, defendants facing copyright infringement claims in the United States may well assert antitrust counterclaims. While such counterclaims often fail, the costs of defending such counterclaims can still be significant, and they can expose claimants to much more wide-ranging discovery obligations than the initial infringement claims would expose them. Moreover, given the underdevelopment and uncertainty of this area of the law, there is still a risk that the counterclaim could be successful, thereby exposing the plaintiff to a claim for treble damages.

Given these costs and potential risks, we would expect owners of IPRs in the United States to try to avoid conduct that could expose them to antitrust claims or counterclaims. Thus, where a plausible antitrust claim exists, owners of IPRs might be less willing to pursue infringement actions and more willing to license their IPRs, or at least, more willing to settle their IP claims on terms favorable to the alleged infringers. By contrast, the limits on private antitrust litigation in Europe means that IP owners seeking to exercise or enforce their IPRs face a lower risk of antitrust liability. ${ }^{171}$

When differences in the processes of antitrust enforcement are taken into account, it appears again that, in certain important respects, the effective degree of protection for IPRs might actually be lower in the United States than it is in Europe. Therefore, any conclusion about the relative degree of protection for IPRs in the United States and Europe based solely on differences in substantive antitrust law is incomplete and potentially misleading. Any such conclusion must follow a serious analysis that accounts, as discussed in previous Parts, for differences between American and European copyright regimes and, as we suggest in this Part, for differences in the processes of antitrust enforcement in those two jurisdictions.

- specified sufficiently precise categories of evidence to be disclosed; and

- satisfied the court that the envisaged disclosure measure is both relevant to the case and necessary and proportionate.

Id. at 5 (emphases omitted).

${ }^{171}$ We note, however, that this outcome may be partly offset in some cases by the availability in the United States of statutory damages and copyright class actions, which by and large, do not exist in Europe. 


\section{EVALUATING THE APPROACHES}

To this point, we primarily have made a descriptive claim as to the relative strength of protection for IPRs in the United States and in Europe. In this part, we provide our thoughts as to why the United States has tended to resort to IP-based, rather than antitrust-based, solutions for restraining the anticompetitive uses of IPRs, while the European Union has instead looked to antitrust to resolve the same problem.

There seem to be three main reasons why the European Union tends to adopt antitrust-based solutions rather than IP-based solutions to curbing anticompetitive uses of IPRs. First, as noted earlier, antitrust and IP law are primarily dealt with by different institutions, thereby leading to a bifurcated system. IP law is largely the domain of the member states, and EU institutions have had relatively little power to influence member states' IP laws. By contrast, antitrust law is largely, though by no means exclusively, developed and enforced at the EU level. This means that when EU institutions seek to constrain the anticompetitive exercise of IPRs in a particular case, they must address that conduct using the tools of antitrust, over which they have jurisdiction, rather than IP, over which they do not.

Second, and related to this bifurcation of antitrust and IP, private antitrust enforcement in Europe is extremely rare, as noted above. Because private enforcement of antitrust is so rare, courts hearing IP cases have a limited opportunity and capacity to hear detailed accounts of the anticompetitive effects of IP-related conduct and to consider IP-based solutions to the questions before them. Even when the law permits infringement defendants to bring antitrust counterclaims, there are, as discussed in the previous Part, lower incentives for and higher barriers to prosecuting such claims. ${ }^{172}$

Third, the generally accepted normative bases for antitrust law and copyright law in European legal thought suggest that courts might, in general, instinctively lean toward an antitrust-based solution to an anticompetitive use of an IP right instead of an IP-based solution. In Europe, as in the United States, competition law is largely seen as an instrument of economic policy. ${ }^{173}$ In many European jurisdictions, however, copyright law is often conceived not as a statutory framework for advancing economic and cultural goals, but merely as a means of legally recognizing the natural rights of authors in their intellectual creations. ${ }^{174}$ Under such conceptions, it might become more diffi-

\footnotetext{
${ }^{172}$ See supra text accompanying notes 157-172.

${ }^{173} \mathrm{EU}$ competition law, however, has also been used to advance the broader political objective of creating a single market.

${ }^{174}$ Stef van Gompel, Formalities in the Digital Era: An Obstacle or Opportunity?, in Global Copyright: Three Hundred Years Since the Statute of Anne, from 1709 to Cyberspace 395, 412-13 (Lionel Bently et al. eds., 2010).
} 
cult to adjust the copyright from within to accommodate innovative-competition concerns, as such concerns can be perceived as entirely distinct from, and incommensurable with, the perceived ideological foundation of copyright law. In such situations, a court may find resort to competition law-as an external set of rules-more attractive or acceptable, as it does not challenge the internal coherence of copyright law.

In each of these three respects, the United States differs from the European Union in a way that makes it easier for U.S. courts to regulate the anticompetitive use of an IPR from within. Initially, in contrast to the European Union's bifurcated jurisdictional structure, U.S. federal courts have jurisdiction over both antitrust law and copyright law. Indeed, as discussed above, in cases involving an allegedly anticompetitive use of IPRs, a plaintiff may bring an infringement action and a defendant may counterclaim for breach of antitrust laws. Because federal courts have jurisdiction over both IP and antitrust law (and the very same judge often has jurisdiction over the IP and antitrust aspects of a particular case), those courts have greater freedom to choose the appropriate avenue to promote innovative competition.

In addition, the availability (and longer history) of private antitrust enforcement in the United States enables defendants in IP cases to set forth the competitive implications of enforcing the IP more easily. This allows the court to consider the competitive effect seriously, on the basis of elaborated arguments and a supporting record, rather than an afterthought in an IP case. As opposed to the natural rights foundations that dominate copyright conceptions in Europe, U.S. jurisprudence emphasizes that copyright is a nothing but a purely statutory scheme designed to promote public goals, to which the private benefits of authors are subordinate. ${ }^{175}$ The frequent attribution of this mandate to the U.S. Constitution's IP Clause ${ }^{176}$ makes American IP jurisprudence more amenable to considering innovative-competition concerns from within. Because both antitrust and IP law share similar normative foundations, courts have greater latitude to choose between them in crafting a solution to a particular problem at the intersection of the two areas of law.

\footnotetext{
175 Feist Publ'ns, Inc. v. Rural Tel. Serv. Co., 499 U.S. 340, 349-50 (1991) (“It may seem unfair that much of the fruit of the compiler's labor may be used by others without compensation. . . . [H] owever, this is not 'some unforeseen byproduct of a statutory scheme.' . . . It is, rather, 'the essence of copyright' $\ldots$ and a constitutional requirement. The primary objective of copyright is not to reward the labor of authors, but ' $[\mathrm{t}] \mathrm{o}$ promote the Progress of Science and useful Arts.' Art. I, $\S 8, \mathrm{cl}$. 8. . . To this end, copyright assures authors the right to their original expression, but encourages others to build freely upon the ideas and information conveyed by a work." (internal references omitted)).

176 U.S. Const. art. I, § 8, cl. 8 ("The Congress shall have Power . . To promote the Progress of Science and useful Arts, by securing for limited Times to Authors and Inventors the exclusive Right to their respective Writings and Discoveries[.]").
} 
Admittedly, these three considerations only explain why U.S. courts can choose IP-based solutions over antitrust-based solutions to address such problems. These considerations do not explain why U.S. courts seem to prefer IP to antitrust solutions in cases where both are equally available. While we do not reach a definitive conclusion on this point, we offer a few possible explanations. One, following Cotter's observation, relates to the fact that in the United States, unlike in most EU jurisdictions, antitrust violations might carry criminal penalties. As a result, a finding that a firm violated the antitrust law might carry greater stigma - and warrant greater caution-than a ruling that denies an IP owner some of its rights. ${ }^{177}$

Another explanation might lie in what William Kovacic calls the "intellectual DNA of modern U.S. competition law" or the "Chicago/Harvard double helix" 178 and perhaps in other factors influencing American judicial attitudes. According to Kovacic, the modern U.S. antitrust attitude towards single-firm conduct is the product of genes inherited from the Chicago School and the Harvard School. The modern attitude has inherited Chicago's skepticism about "the competitive significance of single-firm behavior" 179 and Harvard's concerns about the limits on the institutional capacity of courts entrusted with handling private and public antitrust enforcement. ${ }^{180}$ The combination of these genes tends "to discourage antitrust intervention to control the conduct of dominant enterprises" 181 and "to give dominant firms greater freedom to select pricing, product development, and distribution strategies." 182

Applied to refusal to license IPRs, the effect of Chicago genes could be indeterminate. On the one hand, the refusal could be seen as a benign activity that will only enhance innovation by allowing a greater reward to the rights holder (as Justice Scalia commented in Trinko). ${ }^{183}$ On the other hand, some Chicago scholars regarded reliance on IPRs and judicial enforcement to exclude competitors, especially when the IP claim is of questionable validity, as particularly pernicious anticompetitive or opportunistic behavior. ${ }^{184}$ The Harvard genes, while potentially more receptive to the anticompetitive signifi-

${ }^{177}$ Cotter, supra note 66, at 537.

178 William E. Kovacic, The Intellectual DNA of Modern U.S. Competition Law for Dominant Firm Conduct: The Chicago/Harvard Double Helix, 2007 Colum. Bus. L. Rev. 1, 14-15 (2007); see also Daniel A. Crane, Chicago, Post-Chicago, and Neo-Chicago, 76 U. CH. L. Rev. 1911 (2009).

${ }^{179}$ Kovacic, supra note 178, at 15.

${ }^{180} \mathrm{Id}$. at 14 .

${ }^{181} \mathrm{Id}$. at 15.

${ }^{182} \mathrm{Id}$. at 18.

183 Verizon Commc'ns Inc. v. Law Offices of Curtis V. Trinko, 540 U.S. 398, 407 (2004).

${ }^{184}$ See, e.g., Robert Bork, The Antitrust Paradox 347-49 (1978). The decision of Judge Posner in Assessment Technologies of WI, LLC v. WIREdata, Inc., 350 F.3d 640 (7th Cir. 2003), also illustrates this view. 
cance of the refusal to license, may tend to prefer an IP solution that does not require the court to strain its capacity to understand the matter and to design and oversee an appropriate remedy. If IP law can provide a simple and easily administrable rule (compared to a fact-intensive economic analysis under an antitrust rule of reason), the Harvard genes would favor an IP solution. ${ }^{185}$ Harvard's Phillip Areeda famously labeled the essential facilities doctrine "an epithet in need of limiting principles," 186 suggesting that it lacks guiding standards and provides a vehicle for "baseless or unmanageable antitrust claims." 187 Internal IP solutions avoid such problems precisely because they rely more on the formal categories of IP laws, and less on the complexity and indeterminacy of the rule of reason.

A few other factors influencing American judicial attitudes may contribute to the same outcome. Antitrust in the United States has become much more ideologically polarized along the conservative/liberal divide than has IP. ${ }^{188}$ Given the current composition of the Supreme Court, an IP-based solution may have a higher probability of being upheld (or adopted) by the Supreme Court than an antitrust-based ruling against the holder of the IPR. An antitrust solution may be more politically polarizing than an IP solution because the antitrust solution must presuppose the existence of a property right (the right to exclude), with which judicial fiat would then interfere (possibly at the behest of a competitor). An antitrust solution would require the court to impose trebled damages and attorney's fees, thus triggering anxieties about regulatory takings, price controls, and judicial activism. Finding that there is no IPR to begin with relieves those anxieties. If there is no property right to begin with, it cannot be taken. If no license is necessary, no intervention in the price mechanism is required. And if some provisions of the Copyright Act or, even better, the Constitution (as in Feist) can be interpreted to directly mandate the outcome, the outcome would be seen as less judicially activist than one reached under the broad yet indeterminate language of Section 2 of the Sherman Act. Therefore, to the extent that Supreme Court justices seek consensus, they may prefer a solution based on IP over one based on antitrust. To the

\footnotetext{
${ }^{185}$ Crane, supra note 178, at 1920 (characterizing Justice Breyer's dissent in Leegin Creative Leather Products, Inc. v. PSKS, Inc., 551 U.S. 877, 917 (2007), and his support of a bright-line rule as reflecting a Harvard approach); see also Kirtsaeng v. John Wiley \& Sons, Inc., 133 S. Ct. 1351, 1363 (2013) (Breyer, J.) ("The 'first sale doctrine' also frees courts from the administrative burden of tryng to enforce restrictions upon difficult-to-trace, readily movable goods. And it avoids the selective enforcement inherent in any such effort.").

186 Phillip Areeda, Essential Facilities: An Epithet in Need of Limiting Principles, 58 ANTITRUST L.J. 841, 841 (1990).

${ }^{187}$ Shelanski, supra note 14 , at 372.

${ }^{188}$ That is not to suggest that intellectual property is entirely free of ideological divisions. See Matthew Sag, Tonja Jacobi \& Maxim Sytch, Ideology and Exceptionalism in Intellectual Property: An Empirical Study, 97 Calif. L. Rev. 801 (2009).
} 
extent that lower-court judges seek to have their judgments upheld, rather than reversed, they would frame their decisions accordingly.

In sum, the American approach to achieving a balance between innovation and rivalry through the internal operation of copyright law, rather than the external application of antitrust law, may reflect an American perception that the former is less intrusive on individual freedom and property rights. As we have shown, however, this perception may be illusory. The American IPbased and European antitrust-based approaches yield similar outcomes in many cases, and the American approach actually has the potential to impose greater restrictions on IPRs.

\section{CONCLUSION}

In this article we challenge the conventional wisdom that the European Union has subordinated intellectual property rights in the pursuit of competitive markets to a much greater extent than has the United States. We have shown that, at least in the context of copyright protection and refusals to license, the conventional wisdom is wrong. While European antitrust regulation of IPRs does seem more robust and activist than American antitrust regulation of IPRs, focusing solely on one antitrust doctrine (i.e., a dominant seller's refusal to license its copyright) tells only part of the story. Once various doctrines of copyright law are taken into account, the perceived substantive differences between the European and American approaches become much less pronounced. While European jurisdictions have relatively expansive copyright protection, which competition law may occasionally narrow, American copyright law provides stronger internal limits on copyright protection in a number of circumstances. These internal limits not only lessen the need for antitrust law to police anticompetitive uses of copyrighted works but also promote procompetitive outcomes in a broader range of circumstances. When one also considers the broader impact that antitrust law, beyond its treatment of refusals to deal, might have on the exercise of IPRs in the United States, it becomes apparent that U.S. copyright protections are weaker, in key respects, than those available in Europe.

We recognize the limits of our analysis. We have considered only copyright law, and only specific doctrines within it. We have focused our antitrust discussion almost exclusively on the limits that antitrust places on an IP holder's right to refuse to license. Despite these limitations, however, our analysis does suggest grounds to question the common assumption that differences in how the United States and Europe treat refusals to deal reflect fundamental differences in these jurisdictions' overall approaches to the respective roles of IP and competition law in promoting innovation and consumer welfare. Our analysis suggests tentatively that if such differences exist, it is the United 
States, not Europe, which leans toward placing greater emphasis on competition than on IP.

Reaching firmer conclusions may require inquiries beyond those that it would be possible to undertake within a scope of an article such as this one. Our goal has been to make those inquiries legitimate and, if possible, to give them sharper focus. We have explored the duality between stronger antitrust law and weaker copyright law, and we have compared the American and European experiences in applying both. In so doing, we have shown how different legal tools can be used to achieve a particular balance between short-term rivalry and long-term innovation. Our analysis does not attempt to provide a normative justification for any particular balance. The question of what balance is appropriate is enormously complex. Those who seek to resolve it must face the reality that the answer to the underlying question of how important IPRs are, and what their optimal scope is, remains elusive. ${ }^{189}$

As the discussion continues, therefore, we hope that this article will provide not a grand conclusion, but another perspective-and perhaps a working hypothesis. For, if our observations are correct, and if it is also correct that the United States enjoys higher levels of innovation than most of Europe, then, to the extent that the legal rules actually matter, the "less is more" approach to copyright that the United States has taken might in fact be superior. As the empirical truth of each step in that reasoning is open to debate, however, it remains no more than a conjecture to be confirmed or refuted another day. ${ }^{190}$ But it may be the place to start.

\footnotetext{
189 The answer need not be debilitatingly elusive, however. Cotter's analysis, for example, offers qualified support to the American approach by showing that "the expected harm, including error costs, of ruling for the IP defendant will sometimes be sufficiently low as to counsel in favor of excusing the defendant from liability, even though the potential anticompetitive harm resulting from a ruling for the plaintiff would be unduly speculative or not cognizable at all from the perspective of antitrust." Cotter, supra note 66, at 556-57.

${ }^{190}$ The findings of two recent empirical studies are consistent with this hypothesis. In one study, Harvard Business School's Josh Lerner found that the Second Circuit 2008 decision in the Cablevision case, Cartoon Network, LP v. CSC Holdings, Inc., 536 F.3d 121 (2d Cir. 2008), which reduced the potential copyright liability of cloud services, led to increased venture capital investment in the United States. See Josh Lerner, The Impact of Copyright Policy Changes on Venture Capital Investment in Cloud Computing Companies 1 (2011), available at http://www. analysisgroup.com/uploadedFiles/Publishing/Articles/Lerner_Fall2011_Copyright_Policy_VC_ Investments.pdf. In a follow-up study analyzing the effect of court decisions in Germany and France that held a cloud service provider liable for copyright infringement, he found that those rulings led to a decline in venture capital investment in cloud computing firms in those countries. See Josh Lerner, The Impact of Copyright Policy Changes in France and Germany on Venture Capital Investment in Cloud Computing Companies 1 (2012), available at http://www.analysis group.com/uploadedFiles/News_and_Events//_EU_CloudComputing_Lerner.pdf.
} 